\title{
Selective Distribution of Kainate Receptor Subunit Immunoreactivity in Monkey Neocortex Revealed by a Monoclonal Antibody That Recognizes Glutamate Receptor Subunits GluR5/6/7
}

\author{
G. W. Huntley, ${ }^{1}$ S. W. Rogers, ${ }^{4}$ T. Moran, ${ }^{3}$ W. Janssen, ${ }^{1}$ N. Archin, ${ }^{1}$ J. C. Vickers, ${ }^{1}$ K. Cauley, ${ }^{5}$ S. F. \\ Heinemann, ${ }^{6}$ and J. H. Morrison ${ }^{1,2}$ \\ ${ }^{1}$ Fishberg Research Center for Neurobiology, ${ }^{2}$ Department of Geriatrics and Adult Development, and ${ }^{3} \mathrm{Hybridoma}$ Facility \\ The Mount Sinai School of Medicine, New York, New York 10029, ${ }^{4}$ Department of Pharmacology, University of Colorado \\ Health Science Center, Denver, Colorado 80262, and ${ }^{5}$ Molecular Biology and Virology Laboratory and ${ }^{6}$ Neurobiology \\ Laboratory, The Salk Institute for Biological Studies, La Jolla, California 92037
}

A monoclonal antibody (4F5) was generated against a portion of the putative extracellular domain of glutamate receptor subunit GluR5. Western blot analyses and immunocytochemistry of transfected human embryonic kidney 293 cells confirmed that monocional antibody 4F5 was specific for GluR5, -6 , and -7 (the three identified members of the kainate receptor subunit class), but did not recognize GluR1, -2, or -3 (the AMPA/kainate receptor subunit class). The antibody was subsequently used to examine immunocytochemically the regional, laminar, and cellular distribution of GluR5/6/7 receptor subunits at the light and electron microscopic levels in monkey neocortex.

Receptor subunit immunoreactivity was present throughout all cortical areas examined, but exhibited marked cellular, laminar, and regional specificity. Typically, pyramidal cell somata and apical dendrites were well stained. Electron microscopy revealed an extensive cytoplasmic localization of GluR5/6/7 immunoprecipitate, with intense staining of many postsynaptic densities, all of which were associated with asymmetric synapses located on dendritic shafts or dendritic spines. There was no evidence of stained glial cells or presynaptic axon terminals. In most areas, labeled cells and dendrites were concentrated in layers II, III, and V while layers I, IV, and VI typically possessed the fewest and/or least intensely stained elements. A consistent feature in many areas was groups of clustered layer $\mathbf{V}$ pyramidal cells and bundles of ascending apical dendrites. Regionally, motor areas and higher-order association areas of the frontal,

\footnotetext{
Received Oct. 6, 1992; revised Jan. 12, 1993; accepted Jan. 28, 1993.

This work was supported in part by Grants AG06647 and NS-30990-01 (J.H.M.) and NS 30990R29-01 (S.W.R.) from the National Institutes of Health and a grant from the American Health Assistance Foundation (AHAF) and a research fellowship from the American Cancer Society (K.C.) J.C.V is the recipient of a C. J. Martin Postdoctoral Fellowship from the Australian National Health and Medica Research Council. G.W.H. is an Aaron Diamond Foundation Fellow, and this research is supported in part by a grant from the Aaron Diamond Foundation. We are extremely grateful to Thom Hughes for his assistance in producing the bacterial overexpression constructs, to Jan Egebjerg for providing the GluR6 expression construct, to Bernard Bettler for providing the GluR5 fragment used in these studies prior to publication, to Inder Verma for his continued support of the transfected cell experiments, to Drs. P. Hof and S. Siegel for help with data analysis, and to R. Woolley and J. Woolley for photographic assistance.

Correspondence should be addressed to Dr. J. H. Morrison, Fishberg Research Center for Neurobiology, The Mount Sinai School of Medicine, Box 1065, One Gustave L. Levy Place, New York, NY 10029-6574.

Copyright (C) 1993 Society for Neuroscience $0270-6474 / 93 / 132965-17 \$ 05.00 / 0$
}

parietal, and occipital lobes were more densely stained than primary sensory areas (somatic sensory and visual cortex), which was confirmed quantitatively. These data indicate a high degree of selectivity in the distribution of kainate receptors composed of GluR5/6/7 subunits, and suggest that functional specificity and diversity in the ubiquitous excitatory amino acid-utilizing axonal systems in neocortex are achieved in part by the differential association of particular glutamate receptor subunits with specific cortical circuits. In addition, the regional, laminar, and morphological characteristics of GluR5/6/7-immunoreactive neurons bear a strong similarity to those of the neocortical neurons with heightened vulnerability in certain neurodegenerative disorders.

IKey words: excitatory synaptic transmission, excitatory amino acid receptors, cortical circuitry, primate, immunocytochemistry, electron microscopy]

Cerebral cortical function is critically dependent on fast, excitatory neurotransmission, which is thought to be mediated primarily by the amino acid neurotransmitters glutamate (Glu) and aspartate (Asp) (Streit, 1984). A large number of diverse studies have firmly established the excitatory nature of both thalamocortical relay neurons, the principal route through which sensory information is conveyed to the cerebral cortex, and the majority of intrinsic cortical neurons, which include pyramidal neurons and nonpyramidal spiny stellate neurons. For example, each of these cell populations is immunoreactive for Glu and/or Asp (Ottersen and Storm-Mathisen, 1984; Conti et al., 1987; DeFelipe et al., 1988; Giuffrida and Rustioni, 1989; Montero, 1990; Dori et al., 1992), selectively incorporates and retrogradely transports $\mathrm{D}^{3} \mathrm{H}$-aspartate (Baughman and Gilbert, 1981; Manzoni et al., 1986; Barbaresi et al., 1987; Kisvarday et al., 1989; Johnson and Burkhalter, 1992), furnishes axon terminals whose synaptic contacts are of the asymmetrical variety (LeVay, 1973; Saint Marie and Peters, 1985) and therefore presumably excitatory (Gray, 1969), and, when physiologically stimulated, induces EPSPs in target neurons (Mayer and Westbrook, 1987). The excitatory synaptic activity conveyed by these and other neuronal populations has been implicated in the normal patterning of connections that arise during development (Shatz, 1990), in certain forms of memory and learning (Collingridge and Singer, 1990), in the etiology of some neuropathological diseases (Meldrum and Garthwaite, 1991), and in the estab- 
lishment and maintenance of normal receptive field properties of cortical neurons (Tsumoto, 1990).

The diversity in the effects generated by excitatory amino acid neurotransmitters arises in part from the existence of multiple subtypes of glutamate receptors, which can be broadly segregated into metabotropic receptors that are G-protein linked and ionotropic receptors that form cation-selective channels. Pharmacologically, ionotropic receptors can be further classified by selective agonists into NMDA, 3-hydroxy-5-methylisoxazole4-propionate (AMPA), kainate, and 2-amino-4-phosphonobutyric acid (AP4) subtypes. Recently, molecular cloning studies have identified multiple glutamate receptor subunits that are thought to comprise the non-NMDA ionotropic glutamate receptors. Four of these subunits, GluR1-GluR4 (or GluRAGluRD), share a high sequence identity distinct from other nonNMDA receptor subunits and appear to represent the major AMPA receptor subunits (Hollmann et al., 1989; Boulter et al., 1990; Keinanen et al., 1990; Nakanishi et al., 1990; Sommer et al., 1990; Sun et al., 1992). A second family of cloned nonNMDA receptor subunits has been identified whose members, GluR5-GluR 7, may represent a family of high-affinity kainate receptor subunits (Bettler et al., 1990; Egebjerg et al., 1991; Bettler et al., 1992; Sommer et al., 1992). A third family of closely related genes encodes proteins that also appear to bind ${ }^{3} \mathrm{H}$-kainate with affinities characteristic of high-affinity kainate binding sites (Gregor et al., 1989; Wada et al., 1989; Werner et al., 1991; Herb et al., 1992; Sakimura et al., 1992). Such kainatebinding proteins, termed $\mathrm{KAl}$ and $\mathrm{KA} 2$, are incapable of forming homomeric ion channels when expressed in oocytes, but in heteromeric assemblies can form ligand-gated ion channels. These and other data suggest that non-NMDA ionotropic receptors may be differentially constructed from multiple receptor subunits, although the relationship between actual functional glutamate receptors or receptor complexes found in vivo and the precise combinations of receptor subunits that assemble to form them remains to be determined. Nevertheless, details of the localization and distribution of the individual glutamate receptor subunits in the brain represent an important step toward unraveling the precise complement of particular receptor subunits present in identified neural circuits (see Vickers et al., 1993). In addition, non-NMDA ionotropic glutamate receptors can flux $\mathrm{Ca}^{2+}$ with a magnitude that appears to depend on the subunit composition (reviewed in Gasic and Heinemann, 1992), which has profound implications for the classes of cells potentially vulnerable to neuroexcitotoxicity and some neurodegenerative diseases (Choi, 1988). To date, most studies have focused on the distribution of the mRNAs encoding AMPAselective subunits (Bettler et al., 1990; Boulter et al., 1990; Keinanen et al., 1990; Pellegrini-Ciampietro et al., 1991) or those encoding kainate-selective subunits (Bettler et al., 1990, 1992; Egebjerg et al., 1991; Sommer et al., 1992) in rat brains, which precludes any knowledge of the cellular localization of the subunit proteins and the morphology of the labeled cells. Recently, however, immunocytochemistry using subunit-specific antibodies has been used for localizing at a greater resolution some of the AMPA-selective subunit proteins in rat brains (Rogers et al., 1991; Wenthold et al., 1992). However, nothing is known about the cellular distribution of the kainate-selective subunit proteins, and no studies to date have examined the distribution of any glutamate receptor subunit in primate cortex. We report here the characterization of a monoclonal antibody (mAb) against kainate-selective subunits GluR5/6/7 and describe the light and electron microscopic immunocytochemical localization of these subunits in monkey cortex.

\section{Materials and Methods}

Bacterial overproduction and antibody production. The trpE bacterial overexpression system (Dieckmann and Tzagoloff, 1985) was used to obtain GluR5 antigen for antibody production. A Bg1II-Smal fragment of the GluR5 cDNA (nucleotides 990-1889; Bettler et al., 1990) was shuttle cloned into the BamH1-Hinc2 sites of vector pUC18. This fragment was then removed using Smal and Hind 3 for subcloning into the pATH2 expression vector at the same restriction enzyme sites. Protcin from GluR1 (long construct), GluR2, and GluR3 was the same as previously described (Rogers et al., 1991). The portion of GluR6 used for overproduction was from the Pst 1 site at the codon for amino acid 200 to the Bam $\mathrm{H} 1$ site at the codon for amino acid 376 . Antigen production, enrichment, and purification by SDS-PAGE fractionation were done exactly as described previously (Rogers et at., 1991, 1992).

Soluble fusion proteins were prepared by dissolving enriched antigen into freshly prepared $8 \mathrm{M}$ urea $(10 \mathrm{ml}$ per gram of protein) at room temperature for $1 \mathrm{hr}$. The solution was clarified by centrifugation and the supernatant diluted $1: 10$ by the slow addition of a solution consisting of $50 \mathrm{~mm} \mathrm{KCl}$ and $50 \mathrm{~mm} \mathrm{NaCl}(\mathrm{pH} \mathrm{10.5)}$. After an additional hour of stirring at room temperature, the solution was brought to $\mathrm{pH} 8$ with 1 $N \mathrm{HCl}$ and repeatedly dialyzed against $10 \mathrm{~mm} \mathrm{NaCl}$ in $10 \mathrm{~mm}$ sodium phosphate buffer $\left(\mathrm{pH} \mathrm{7.2)}\right.$ at $4^{\circ} \mathrm{C}$. The concentration of soluble protein was then measured by the method of Lowry (Lowry et al., 1951; BioRad).

Monoclonal antibodies were produced by immunizing 6-8-week-old BALB/c mice with polyacrylamide gel strips emulsified in Complete Freund's Adjuvant in the foot pads and intraperitoneally. The animals were boosted after 3 weeks with gel strips emulsified in Incomplete Freund's Adjuvant. Boosts were repeated two additional times at monthly intervals. Serum antibody titers were checked by Western blotting (described below) and the animal with the highest titer was selected for fusion. Ten million SP2/0 BALB/c myeloma cells were mixed with 100 $\times 10^{6}$ spleen cells and fused by the dropwise addition of PEG 4000 using a standard technique. Colonies were visible $12 \mathrm{~d}$ later and supernatants were removed and analyzed for the presence of specific antibodies by radioimmunoassay. Falcon microtest III plates were coated with $2.5 \mu \mathrm{g} / \mathrm{ml}$ of fusion protein or trpE overnight at $4^{\circ} \mathrm{C}$. Undiluted supernatants $(50 \mu \mathrm{l})$ were added to each plate, incubated $2 \mathrm{hr}$, and washed carefully, and $50,000 \mathrm{cpm}{ }^{12} \mathrm{I}$-labeled rat anti-mouse kappa light chain antibody was added to each well. After a $2 \mathrm{hr}$ incubation, the wells were washed, the plates were cut up, and radioactivity was determined in a gamma counter. Hybridomas producing antibody that bound only to the fusion protein were retested and, if positive, cloned by limiting dilution. Clones producing the desired antibody (antibody 4F5) were injected into pristane-primed BALB/c mice and the ascitic fluid was collected and used in subsequent experiments.

Brain dissection and fractionation. Young Fisher rats were killed, and the brains were immediately removed from the cranium, stored in icecold dissection buffer ( $50 \mathrm{~mm}$ Tris-acetate, $\mathrm{pH} 7.4 ; 10 \%$ sucrose; $5 \mathrm{~mm}$ EDTA) containing a freshly added protease inhibitor cocktail of $1 \mathrm{~mm}$ phenylmethylsulfonyl fluoride, $20 \mu \mathrm{g} / \mathrm{ml}$ benzamidine, and $20 \mu \mathrm{g} / \mathrm{ml}$ iodoacetamide prior to dissection as described previously (Rogers et al., 1991). Brain regions examined included the cortex, hippocampus, and cerebellum. For monkey brain (Macaca fascicularis), postmortem tissue was removed from the hippocampus, cerebellum, and several areas of the neocortex and frozen immediately on dry ice. These samples were then placed in dissection buffer and processed as described for rat brain tissue.

Western blot analysis. Proteins that were fractionated using SDSPAGE were transferred overnight at $4^{\circ} \mathrm{C}$ to nitrocellulose $(\mathrm{pH} 7.9,0.1$ $\mu \mathrm{m}$ pore size, Schleicher and Schuell) using a Hoeffer TE- 65 tank transfer system containing freshly prepared transfer buffer (10 mM MOPS; $4 \mathrm{~mm}$ sodium acetate, $\mathrm{pH} 7.5 ; 20 \%$ ethanol; $0.1 \% \mathrm{SDS}$ ) as described previously (Rogers et al., 1991). The blots were blocked with Blotto (3\% nonfat dry milk in PBS) and then exposed to primary antibody (1:10 4F5 hybridoma media, Blotto) overnight at $4^{\circ} \mathrm{C}$. The blots were then washed in Blotto, transferred to Blotto containing 1:1000 goat anti-mouse IgG + IgM alkaline phosphatase-coupled secondary antibody (Jackson ImmunoResearch) for $1 \mathrm{hr}$ at room temperature, washed with developing buffer ( $50 \mathrm{~mm}$ sodium carbonate, $2 \mathrm{~mm}$ magnesium sulfate, $\mathrm{pH}$ 9.5 ), and then developed in developing buffer containing $1 \mathrm{mg} / \mathrm{ml} \mathrm{ni-}$ 
troblue tetrazolium and $0.5 \mathrm{mg} / \mathrm{ml}$ BPTI (bovine pancreatic trypsin inhibitor). Development was stopped with PBS/1 mM EDTA.

Cell transfection and immunocytochemistry. Immunocytochemistry of 293 cells (human adenovirus-transformed primary kidney cells, ATCC CRL 1573) transfected with either GluR1, GluR2, GluR3, GluR6, or GluR 7, respectively, were used to evaluate subunit specificity of monoclonal antibody (mAb) 4F5. Full-length cDNAs encoding the above subunits were subcloned into cytomegalovirus (CMV)-driven expression vectors. Kidney 293 cells were subcultured onto coverslips in sixwell culture dishes (Corning) at a density of approximately $10^{4}$ cells/ well and grown for $24 \mathrm{hr}$ in Dulbecco's modified Eagle's medium with $10 \%$ fetal calf serum in a humidified atmosphere containing $5 \% \mathrm{CO}_{2}$ at $37^{\circ} \mathrm{C}$. These cells were then transfected overnight with $5 \mu \mathrm{g}$ of cesiumbanded plasmid DNA per well using the calcium phosphate method (Chen and Okayama, 1987). The culture media were changed the following morning. Cells were fixed $24-48 \mathrm{hr}$ later for $30 \mathrm{~min}$ at $37^{\circ} \mathrm{C}$ by adding an equal volume of $4 \%$ freshly prepared paraformaldehyde (Electron Microscopy Sciences) in $0.2 \mathrm{~m}$ cacodylate buffer. The fixative was removed and cells were blocked and permeabilized as described previously (Rogers et al., 1992) except that goat anti-mouse IgG + IgM coupled to horseradish peroxidase (Jackson ImmunoResearch) was used as the detection system.

Animals used for immunocytochemistry. The brains from 10 adult cynomolgus monkeys (Macaca fascicularis) weighing between 2.5 and $4 \mathrm{~kg}$ were used for immunocytochemistry of tissue sections in this and a related study (Vickers et al., 1993). For each cortical region examined, a minimum of seven brains were used for analysis. The care and treatment of all animals was in accordance with institutional and NIH guidelines. All animals were deeply anesthetized with ketamine $(25 \mathrm{mg} / \mathrm{kg})$ and Nembutal $(30 \mathrm{mg} / \mathrm{kg})$ and perfused transcardially initially with cold $1 \%$ paraformaldehyde for $60 \mathrm{sec}$ followed by cold $4 \%$ paraformaldehyde for 8-10 min. Aldehyde solutions were prepared with $0.1 \mathrm{~m}$ phosphatebuffered saline (PBS; pH 7.4). Brains were immediately removed and blocked.

Tissue preparation and immunocytochemistry: light microscopy. Blocks of tissue for light microscopic immunocytochemistry were postfixed in $4 \%$ paraformaldehyde for an additional $6 \mathrm{hr}$ before cyroprotection in a graded series of sucrose solutions $(12 \%, 16 \%$, and $18 \%$ in $0.1 \mathrm{M}$ phosphate buffer) and subsequent freezing in dry ice. In some cases, blocks containing motor or anterior cingulate cortex were flattened prior to freezing. Sections were processed in one of two ways. A series of frozen, $40-\mu \mathrm{m}$-thick sections was cut on a sliding microtome into cold PBS containing $0.3 \%$ Triton $\mathrm{X}-100$ and $5 \%$ nonfat milk powder. After incubation for $2 \mathrm{hr}$, sections were transferred to an identical solution that contained, in addition, the primary antibody 4F5 diluted 1:1000. After a $48-72 \mathrm{hr}$ incubation at $4^{\circ} \mathrm{C}$, sections were processed by the avidinbiotin-peroxidase method using Vectastain ABC kits (Vector Labs, Inc.), reacted with 3,3'-diaminobenzidine tetrahydrochloride (DAB) and $0.01 \%$ hydrogen peroxide, mounted, and coverslipped. A second, alternative series of $40-\mu \mathrm{m}$-thick sections was first incubated in $10 \%$ dimethyl sulfoxide (diluted with PBS) and then refrozen by suspension in 2-methylbutane whose temperature was equilibrated with that of liquid nitrogen. Sections were then thawed in PBS, incubated in primary antibody solution for $48 \mathrm{hr}$, and processed for immunocytochemistry in the exact manner described above. This second procedure was done to possibly enhance antibody penetration. However, the appearance of the immunocytochemical staining was similar between the two tissue processing conditions. All subsequent data analysis was performed on tissue processed in either manner.

Tissue preparation and immunocytochemistry: electron microscopy. Blocks of tissue were postfixed for $6 \mathrm{hr}$ in 4\% paraformaldehyde in PBS. Sections $80 \mu \mathrm{m}$ thick were then cut on a Vibratome, incubated in primary antibody solution for $72 \mathrm{hr}$, and processed for immunocytochemistry as described in the first tissue processing procedure above, without the additional freeze-thaw step. After the reaction with $\mathrm{DAB}$, sections were postfixed for $1 \mathrm{hr}$ in $1 \%$ osmium tetroxide. Sections were then dehydrated in ethanols followed by immersion in acetone, infiltrated with Araldite resin, flat embedded, and polymerized at $58^{\circ} \mathrm{C}$ for $24-48$ $\mathrm{hr}$ (DeFelipe and Fairén, 1992). Sections were cut at $50-70 \mathrm{~nm}$, collected on 300-mesh grids, and viewed unstained on a Hitachi 7000 electron microscope.

Immunocytochemical controls. Control procedures consisted of processing tissue sections immunocytochemically as described except for the omission of the primary antibody $4 \mathrm{~F} 5$, which resulted in no specific staining. In addition, the specificity of $\mathrm{mAb} 4 \mathrm{~F} 5$ was tested by pread- sorption of the antibody with an excess of purified GluR1, GluR2, GluR3, or GluR5 peptides. Immunocytochemistry was then carried out on tissue sections exactly as described above. The pattern of immunostaining following blocking with GluR $1,-2$, and -3 was identical to the pattern found using unblocked mAb 4F5. Blocking with GluR5 resulted in no specific staining (these data not shown).

Data analysis. Sections were viewed and photographed under conditions of normal bright-field optics and differential interference contrast optics, which in some cases optimized the visualization of the finely stained processes. Two types of analyses were performed on stained sections using a Zeiss Axiophot photomicroscope equipped with a computer-driven stage and a high-sensitivity CCD camera interfaced with a DEC 3100 workstation and a Macintosh II microcomputer employing custom morphometry software developed in the laboratory in collaboration with Scripps Research Institute. First, in the flattened sections through cingulate and motor cortex, an estimation of the degree of clustering of stained dendrites in layers II and V cut in cross section was provided by exporting and digitizing for analysis two adjacent microscope fields. In each case, the distribution of the stained dendrites was subjected to a nearest neighbor analysis and the mean density was determined, both using standard algorithms. Then, to determine the degree of clustering of stained dendrites, the mean nearest neighbor data $(m)$ were used to assess the relative degree of randomness with which the stained dendrites were distributed by relating $m$ to the mean density $(D)$ by the formula $r=2 \sqrt{D}(m)$ (Morrison et al., 1984). By this relationship, $r$ reflects the randomness of the distribution. If $r=1$, the distribution is considered random; $r>1$ suggests a nonrandom distribution, while $r<1$ suggests a clustered distribution. In the second type of quantitative analysis, the density of immunolabeled somata within $400-\mu \mathrm{m}$-wide traverses from pia mater to white matter was determined for three of the cortical areas examined [areas 9, 17 (V1), and 18 (V2)]. Stained somata were counted and density determined from five separate traverses for each area from three monkeys. For each area examined, the data were pooled across the three monkeys following a one-way analysis of variance (ANOVA) that indicated no statistical differences between values; the mean densities of the areas were then compared and statistical significance assigned following a second ANOVA and a series of paired Student's $t$ tests.

The delineation of cortical areas was based primarily on the nomenclature of Brodmann (1905) and Walker (1940), and was determined by comparison with a series of sections adjacent to those used for immunocytochemistry that was stained with thionin.

\section{Results}

Specificity of mAb 4F5

$\mathrm{mAb} 4 \mathrm{~F} 5$ was prepared to a portion of the putative extracellular domain of GluR5 receptor subunit protein (amino acids 233 518) using the trpE bacterial expression system as described previously (Rogers et al., 1991). For Western blot analysis, fusion proteins corresponding to the overlapping regions of the closely related GluR 1 (long form, amino acids 185-521), GluR2 (amino acids 175-430), GluR3 (amino acids 245-451), GluR5 (amino acids 233-518), and the putative cytoplasmic domain of GluR1 (amino acids 658-889) were prepared exactly as described previously (Rogers et al., 1991; see Bettler et al., 1992, for amino acid numbering). mAb 4F5 showed strong immunoreactivity toward the GluR5 fusion protein, but not fusion proteins prepared from GluR1, GluR2, or GluR3 (Fig. 1A). In addition, a fusion protein derived from a construct of GluR6 (amino acids 200-376, kindly provided by Jan Egebjerg, Salk Institute) that only partially overlapped with the GluR5 construct was not detected by mAb 4F5 on Western blots (data not shown).

Human embryonic kidney 293 cells were transiently transfected with a CMV-based expression plasmid containing cDNAs encoding either full-length GluR1, GluR2, GluR3, GluR6, or GluR7, respectively. GluR4 and GluR5 were not included becausc of a lack of a form of the cDNA that produces functional receptors when transfected into Xenopus oocytes or cultured 


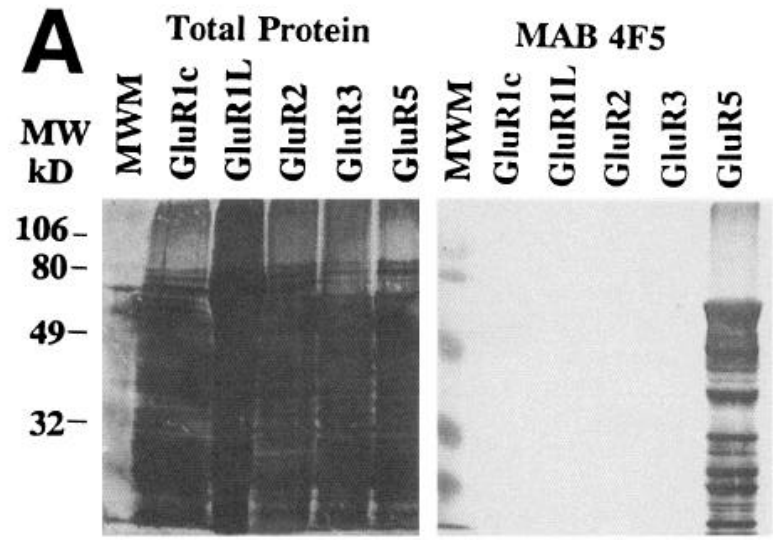

Figure 1. mAb 4F5 subunit specificity. $A$, Fusion proteins encoding the putative cytoplasmic portion of GluR 1 , and overlapping portions of the putative extracellular domains of GluR IL (GluR1, long construct), GluR2, GluR3, and GluR5 were size fractionated using SDS-PAGE and then transferred to nitrocellulose as described in Materials and Methods. The Western blot on the left shows total immunoreactivity using a rabbit anti-trpE polyclonal antibody (see Materials and Methods). An equivalent blot on the right exhibits immunoreactivity revealed using mAb 4F5. Proteins that are lower molecular weight than the fusion protein result from degradation during preparation. Molecular weights are indicated and are based upon the prestained molecular weight markers obtained from Bio-Rad. $B$, Immunocytochemical analysis with $\mathrm{mAB} 4 \mathrm{~F} 5$ of human embryonic kidney cells transfected with CMV-based expression plasmid containing either GluR1, GluR2, GluR3, GluR6, or GluR7 (see Materials and Methods). A nontransfected set of cells served as the control. Immunoreactivity was visualized employing a goat anti-mouse IgG + IgM antibody coupled to horseradish peroxidase. Only cells transfected with GluR6 or GluR7 exhibit immunoreactivity, and examples are indicated with arrowheads. Scale: $2 \mathrm{~cm}=50 \mu \mathrm{m}$.
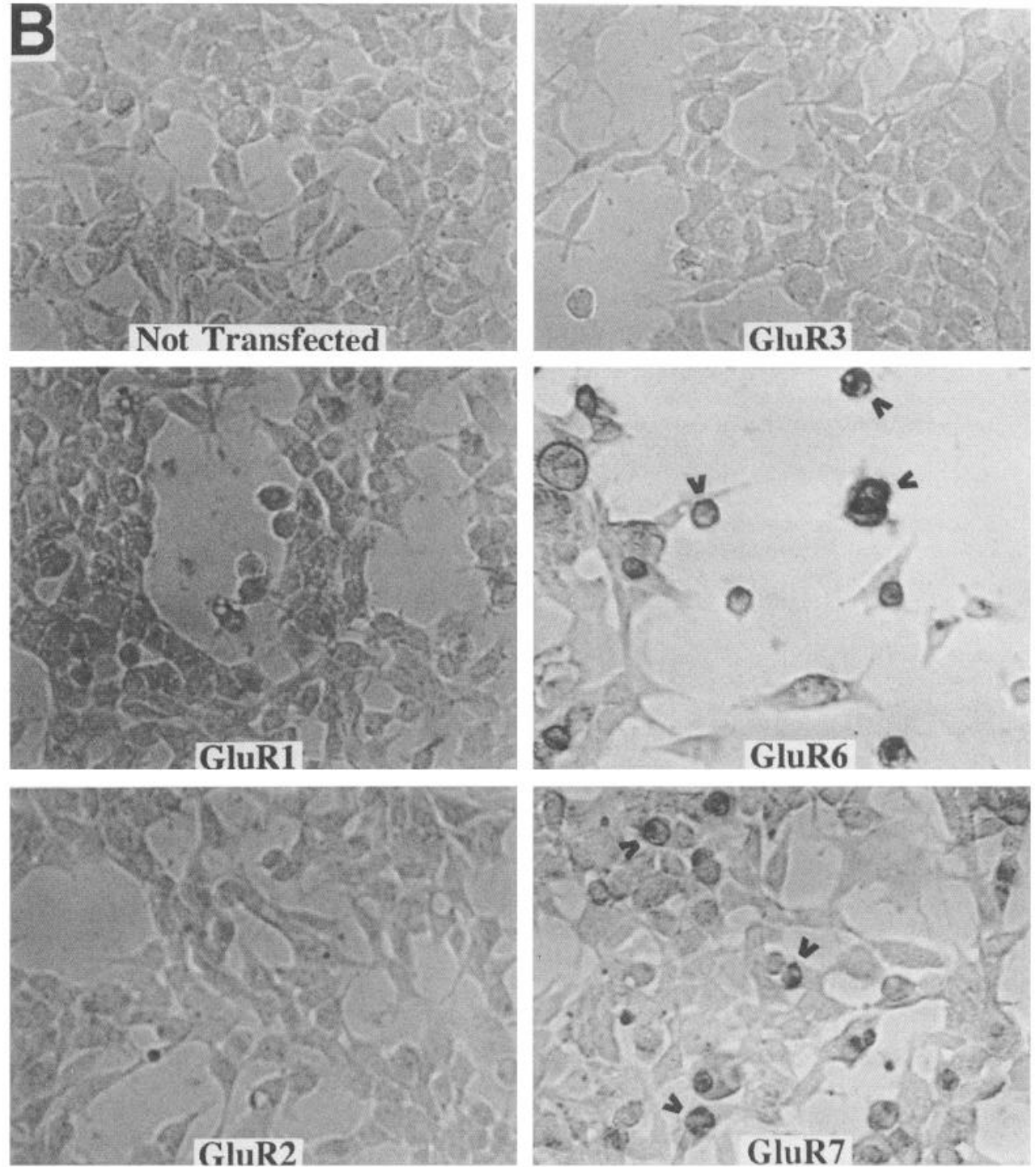

cells (Boulter et al., 1990; Bettler et al., 1992). One to two days later, the transfected cells were fixed and permeabilized with Triton X-100, and immunoreactivity to either mAb 4F5 (Fig. $1 B$ ) or rabbit anti-GluR1 polyclonal serum 5011 (not shown; Rogers et al., 1991) was visualized. mAb 4F5 immunoreactivity was observed in kidney 293 cells transfected with GluR6 or GluR7, but not in kidney 293 cells transfected with GluR1, GluR2, GluR3, or nontransfected cells (Fig. 1B). In the same transfection, immunoreactivity to rabbit polyclonal antibody 5011 was observed only in cells transfected with GluR1 (data not shown; T. Hughes, K. Cauley, and S. W. Rogers, unpublished observations).

mAb 4F5 was used to identify the immunoreactive species in crude membrane preparations of primate CNS tissue using Western blot analysis (data not shown). In monkey tissue, a band of molecular weight $110 \mathrm{kDa}$ was observed that was en- 

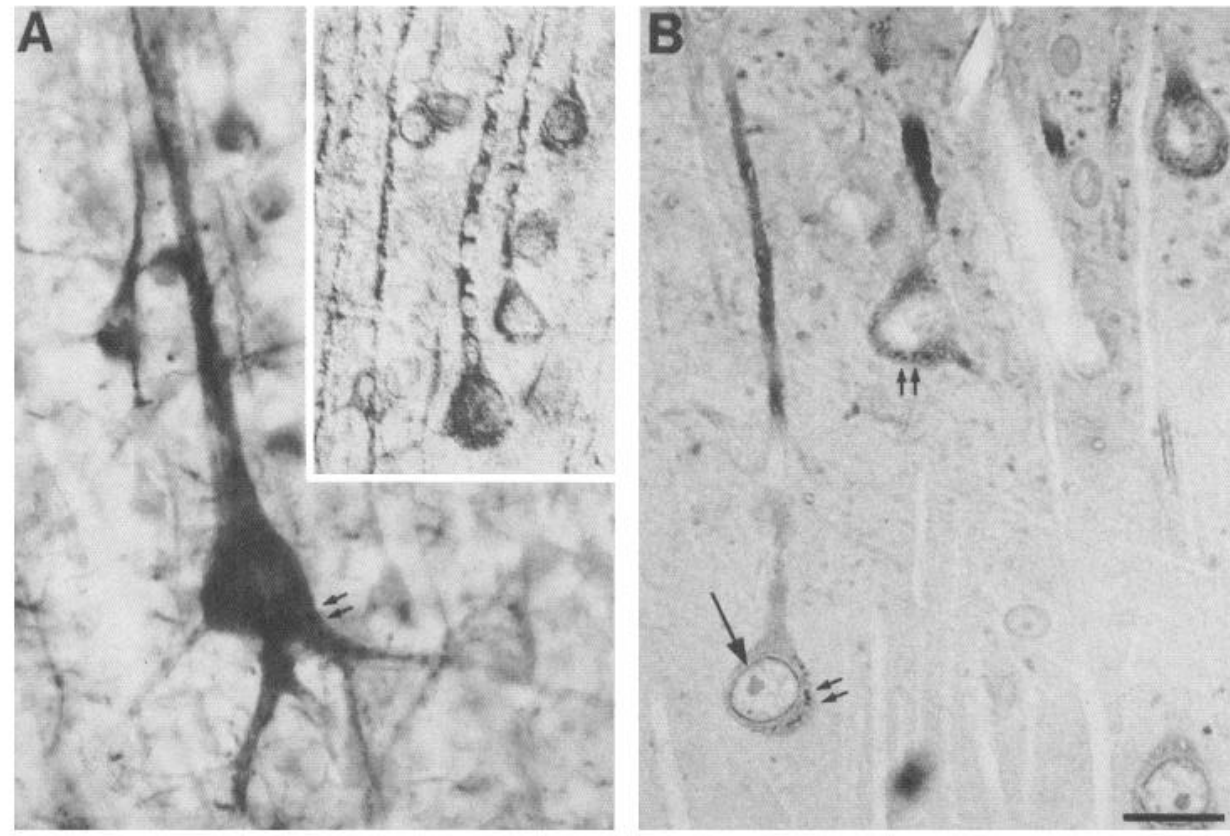

Figure 2. Bright-field photomicrographs showing the cellular staining pattern of GluR 5/6/7 immunoreactivity in $40-\mu \mathrm{m}$-thick sections through area $4(A)$ and area 46 (inset, $A$ ) and in a 3 $\mu \mathrm{m}$ plastic-embedded section through area $24(B)$. Pyramidal cell somata and apical dendrites were well stained; proximal basilar dendrites were stained in some cases $(A)$. Immunoreactivity lined the nuclear membrane (single arrow, $B$ ) and often appeared punctate (double arrows in $A$ and $B$ ) or, along apical dendrites, perforated with unstained areas (inset, A). Scale bar, 40 $\mu \mathrm{m}$.

riched in the cerebral cortex, but was also present in cerebellum and hippocampus. In addition, a doublet of high molecular weight was also observed in each of the three areas, although the detection of these larger bands was inconsistent between preparations. Previous studies using antisera directed against GluR1 (Rogers et al., 1992) and other GluR species (Wenthold et al., 1992) have also described an inconsistent, high-molecular-weight band in rat cortex.

\section{Light microscopic localization of GluR5/6/7 subunit immunoreactivity in monkey neocortex}

\section{General characteristics}

Immunocytochemistry using mAb 4F5 revealed GluR5/6/7 subunit immunoreactivity present throughout all cortical areas examined, which included anterior cingulate cortex (area 24), areas of the prefrontal cortex (areas 46, 9, 12, and 11), motor cortex (areas 4 and 6), first somatic sensory cortex (SI; areas 3a, $3 \mathrm{~b}, 1$, and 2), superior parietal lobule [areas 5 (V1) and 7 (V2)], and primary and secondary visual cortex (areas 17 and 18). The laminar and cellular distribution and density of the receptor subunit immunoreactivity, however, varied substantially across cortical areas (detailed below). Generally, in all regions, pyramidal cells appeared to represent the majority of all immunoreactive cells based on the common presence of prominent, labeled apical dendrites emanating from stained somata (see Figs. 2-6). Usually, a few basilar dendritic processes could be visualized, although this was more variable than the presence of labeled apical dendrites (see Figs. 2A, 3-6). A minority of immunolabeled cells, mostly present in superficial layers, possessed only stained somata and therefore could not be identified definitively as pyramidal or nonpyramidal (e.g., Fig. 3; see Vickers et al., 1993). In general, the staining intensity of somata varied. Some were very intensely stained, others were more lightly stained (e.g., Fig. 3). In light microscopic material, immunoreactivity typically appeared to be present throughout the cytoplasm and often appeared to rim the nuclear membrane (single arrow, Fig. 2B). In some cases, immunoreactivity often appeared punctate, particularly on segments of proximal den- drites or on the somata (double arrows, Fig. $2 A, B$ ). The punctate reaction product was often interspersed with regions lightly and relatively homogeneously stained, but in some cases, particularly on apical dendrites, puncta were present on otherwise immunonegative portions (inset, Fig. $2 A$ ). Neuroglial cells did not appear labeled in the cortical gray matter or in the underlying white matter.

\section{Regional staining pattern}

Anterior cingulate cortex. Anterior cingulate cortex (area 24) was densely immunoreactive and possessed immunolabeled somata and fibers in all cell-dense layers (Fig. 3A). Staining in layer I was much lower overall. The overall staining pattern, however, was characterized by two main features: the presence of a concentrated band of immunoreactive cells corresponding to layer II through the upper half of layer III, and the presence of multiple, vertically oriented, thick, immunoreactive fibers that spanned most of the width of the cortex from layer VI through the upper half of layer III (Fig. 3A). The majority of the immunolabeled cells in superficial layers possessed somata and proximal apical dendrites that were more intensely immunoreactive in comparison with more lightly stained cell somata present in deeper layers (Fig. $3 A$ ). In some cases, such deeply situated cells could be seen giving rise to an apical dendrite that became more intensely immunoreactive in comparison with their parent cell soma. Such apical dendrites often coalesced with other intensely stained fibers, forming bundles of ascending dendrites (arrows, Fig. $3 \mathrm{~A}$ ) that tended to dissipate upon reaching the superficial band of cells in layer III. In other cases, the parent cell somata of the ascending fibers were not detectable. A more detailed tangential analysis of the distribution of the ascending dendrites was performed and is described below.

Prefrontal cortex. In area 46, the overall density of immunoreactivity appeared less than that described for anterior cingulate (compare Fig. $3 A, B$ ). Stained somata were distributed throughout layers II, III, and V, with more lightly stained somata present in layer VI and occasionally in layers IV and I (Fig. $3 B$ ). 
Figure 3. Differential interference contrast photomicrographs showing the laminar distribution, density, and pattern of GluR5/6/7 subunit immunoreactivity in anterior cingulate $(A)$ and area $46(B)$. In both areas, bundles of ascending fibers were present (straight single arrows). In area 46 , such bundles appeared to originate primarily from clusters of layer $\mathrm{V}$ cells (curved arrow, $B)$ and were limited to layers IV and the deep half of III (double arrows, B). Scale bar, $100 \mu \mathrm{m}$.

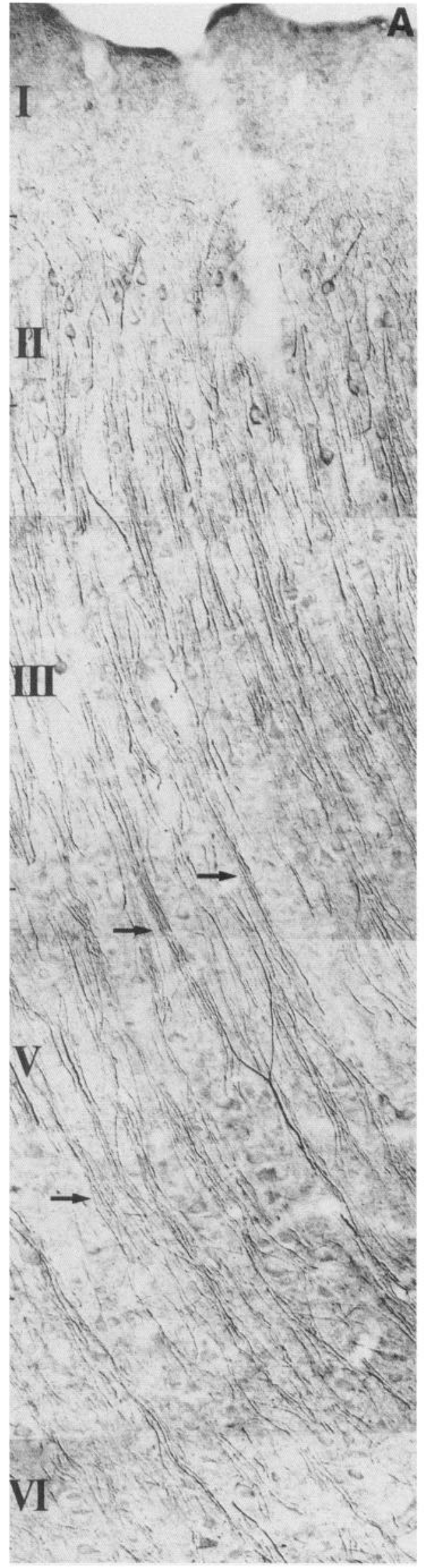


Very few stained fibers were present in layer I. In most cases, each stained soma gave rise to a stained segment of proximal apical dendrite that could be followed for short distances, but usually never into layer I (Fig. $3 B$ ). In layer $\mathrm{V}$, larger, intensely stained pyramidal cells were often grouped in clusters of three to five (curved arrow, Fig. $3 B$ ), and were interspersed with more lightly stained, evenly distributed cell somata. Arising from the clustered layer $\mathrm{V}$ cells were discrete bundles of darkly stained apical dendrites that ascended superficially through the lower half of layer III (single straight arrows, Fig. $3 B$ ), at which point the immunoreactivity decreased or appeared to cease altogether (double arrows, Fig. $3 B$ ). Between the darkly stained dendritic bundles and present in other layers were more lightly stained segments of fibers, mostly oriented perpendicular to the pial surface. In gencral, very few basilar dendritic processes were stained (Fig. 3B).

The overall density of stained somata in dorsomedial prefrontal cortex (area 9) appeared qualitatively greater than that in area 46 (compare Figs. $3 B, 4 A, B$ ). Immunoreactive cells were present in all layers, but were concentrated in a broad band corresponding to layers II and III (Fig. 4A). As in other areas, each stained soma in superficial layers usually gave off a prominent apical dendrite that could be followed for short distances but the labeled portion usually never appeared to ascend into layer I. In layer V, two to five larger, more intensely stained pyramidal cells were clustered and gave rise to prominent bundles of ascending dendrites that spanned layers IV and the deeper half of layer III (Fig. 4B). In layer VI, labeled cells and fibers were lightly stained and evenly distributed.

Throughout ventrolateral and orbitofrontal cortex, the density, laminar distribution, and pattern of GluR5/6/7 subunit immunoreactivity were similar to that already described for area 46 (data not shown).

Motor cortex. The primary motor cortex (area 4) possessed immunoreactive somata and fibers in all layers, although stained somata were concentrated in superficial layers (Fig. 4C) and there were only very thin, sparse fibers in layer I. In addition, a major feature was the presence of large, intensely stained cells in layer V (Fig. $4 D, E$ ). Such large cells often were clustered into groups of three to five (Fig. $4 D$; arrows, Fig. $4 E$ ), but could also be found singly. Typically, each gave off an equally intensely stained apical dendrite, which in some cases could be followed for several hundred micrometers into overlying layers and often coalesced with other ascending dendrites to form a bundle. These fiber bundles were analyzed in tangential sections, which is described below. Many smaller pyramidal cells-some lightly stained and others more intensely stained-were found interspersed between the large cell clusters and in other layers. Short lengths of basilar dendrites were also occasionally observed (Figs. $2 A, 4 D$ ). In addition, segments of radially oriented, thick fibers were also present in the middle layers, but could not be traced back to parent cell somata. The staining pattern in the adjacent premotor area (area 6) was largely similar to that described in area 4 (data not shown).

Parietal cortex. There were no apparent differences in the pattern of immunostaining across the four areas that comprise SI; thus, they are described together. The overall density of immunostaining in SI appeared qualitatively lower than in motor or prefrontal cortex (Fig. $5 A, B$ ). Few immunoreactive cells were present in layer I. Layers II and III possessed lightly labeled, evenly distributed cells (Fig. $5 A, B$ ), many of which gave rise to a stained apical dendrite that could be followed to the border of layers I/II, but usually never into layer I. Occasional, more intensely stained cells were present in the deeper half of layer III (Fig. $5 B$ ). There were few stained cells in layer IV; those present were mostly lightly stained (Fig. $5 A, B$ ). The most distinguishing feature of receptor immunoreactivity in SI was the presence in layer $\mathrm{V}$ of regularly spaced clusters of several, darkly stained, large pyramidal cells (Fig. $5 A$; arrows, Fig. $5 B$ ), many of which gave off an intensely stained apical dendrite that coalesced with other dendrites forming a bundle that traversed radially through layer IV and into the lower half of layer III (Fig. $5 A$ ). In layer VI, only very lightly stained cells were present and no darkly stained fibers either singly or in bundles were evident (Fig. 5B).

In areas 5 and 7, the basic laminar distribution of GluR5/6/ 7 immunoreactivity was similar to that described for SI (Fig. $5 C, D)$. However, the density and intensity of stained somata, particularly in layers II and III, appeared qualitatively greater than in SI (Fig. 5C). In addition, the conspicuous cell clusters described for layer V of SI were not as apparent in cortex of the superior parietal lobule (Fig. $5 D$ ). Instead, intensely stained cells were more evenly distributed.

Occipital cortex. Visual area V1 was the most lightly stained area of all regions examined. The majority of labeled cells were present in layers II and the superficial half of layer III (Fig. 6A). Scattered, lightly immunoreactive somata were present in layer IVB, and occasional, more intensely labeled cell somata were present in layer IVC. Layers V and VI possessed lightly labeled cell somata, with an occasional, relatively large, more intensely labeled cell at the layer V/VI border (arrow, Fig. $6 \mathrm{~A}$ ). In contrast to other arcas described, the immunorcactivity was mostly confined to the somatic region, and only occasionally was a small segment of stained proximal apical dendrite observed. There were no prominent bundles of stained apical dendrites present in $\mathrm{Vl}$ (Fig. 6A).

In $\mathrm{V} 2$, the overall density of immunoreactive somata was greater than in V1 (compare Fig. 6A,B; see also below). The majority of stained cells formed two bands that corresponded to layer II and to the lower half of layer III (Fig. 6B). Such cells were fairly evenly distributed, and usually displayed only short segments of apical dendritic staining. Layers IV, V, and VI possessed fewer stained cells; occasional, well-stained, large pyramidal cells in layer V were observed (arrows, Fig. 6B). Such cells usually displayed prominent basilar dendritic staining and limited apical dendritic staining. No prominent bundles of ascending apical dendrites were observed.

\section{Quantitative analysis of areal density}

The density of immunolabeled somata was compared across three cortical areas: prefrontal cortex (area 9), visual association cortex (V2), and primary visual cortex (V1). All immunolabeled somata, ranging from intensely to lightly stained, were counted. Data from each area were collected from five 400- $\mu \mathrm{m}$-wide traverses per animal extending from pia mater to white matter (see Materials and Methods). Within areas, there were no statistical differences between the densities of immunolabeled somata across animals; thus, data were pooled across animals. A comparison of the mean densities between each area revealed statistically significant differences (Fig. 7). Among the three areas examined, the density of immunolabeled somata in area 9 was greatest, that of V2 intermediate, and that of V1 the lowest. 

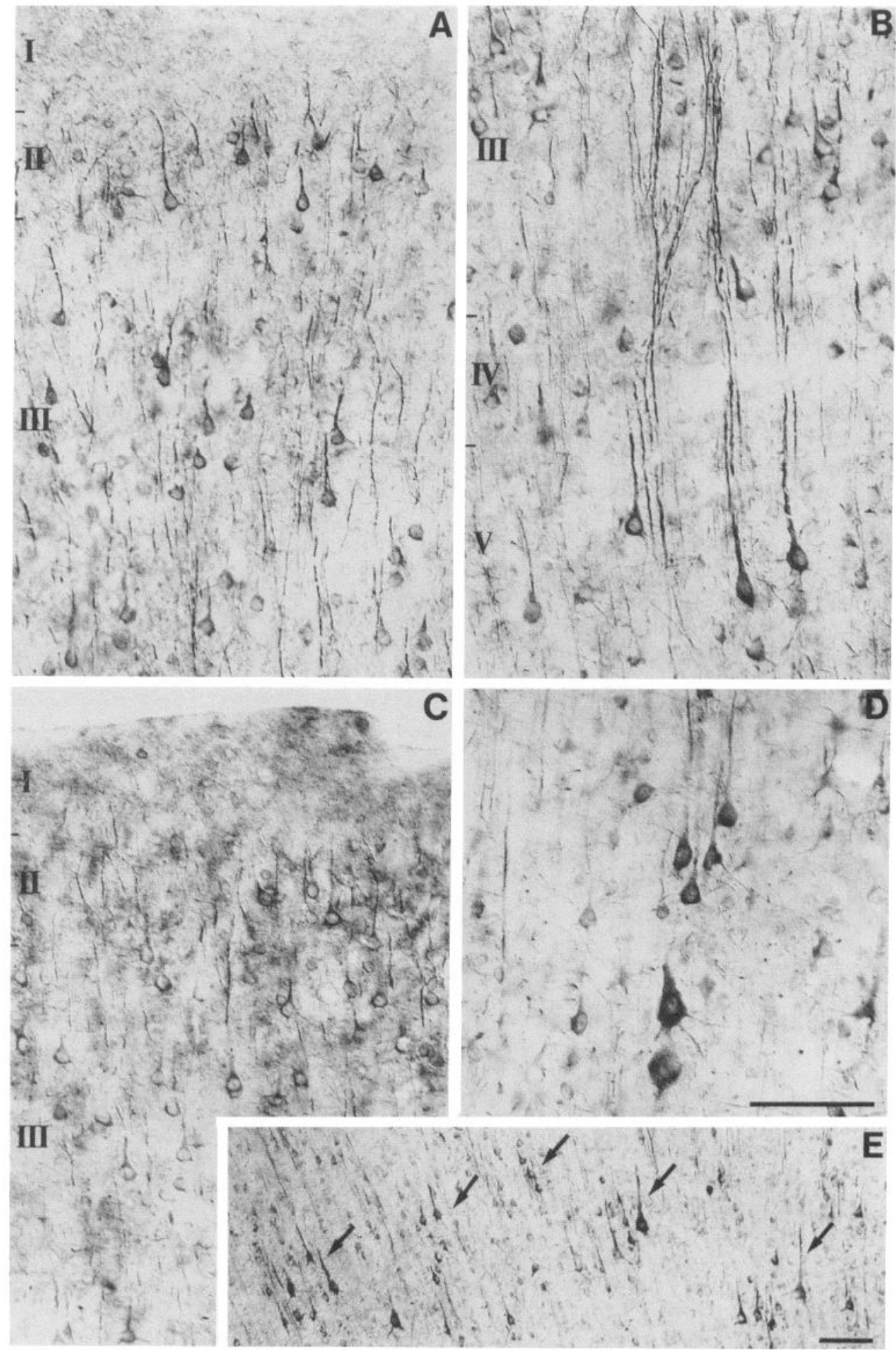

Figure 4. Differential interference contrast photomicrographs through area $9(A, B)$ and through area $4(C-E)$ showing laminar distribution, density, and pattern of GluR5/6/7 immunoreactivity. Clusters of layer $\mathrm{V}$ cells were present in area 4 (arrows, E), one of which is shown at higher power in $D$. Scale bars, $100 \mu \mathrm{m}$.

\section{Tangential analysis of immunolabeled dendrites}

Sections cut parallel to the pial surface from flattened blocks of motor and anterior cingulate cortex were used to examine the nature of the tangential distribution of immunolabeled dendrites in layers II and V. No attempt was made to follow single dendrites or groups of dendrites through successive layers by serially reconstructing sections.

Many of the stained dendrites cut in cross section appeared as intensely labeled dots of variable diameter (Fig. 8). Other cut dendrites were more lightly labeled, and a fine meshwork of lightly labeled, thin processes was observed that coursed in the tangential plane of section. In layer II of cingulate cortex (Fig. $8 A$ ), the darkly stained, cut dendrites appeared qualitatively to be more diffusely distributed in comparison to the tangential distribution of those in layer $\mathrm{V}$, which appeared clustered into groups of 3-12 (arrows, Fig. 8B), separated by larger regions in which single, darkly stained dendrites and numerous, more lightly 


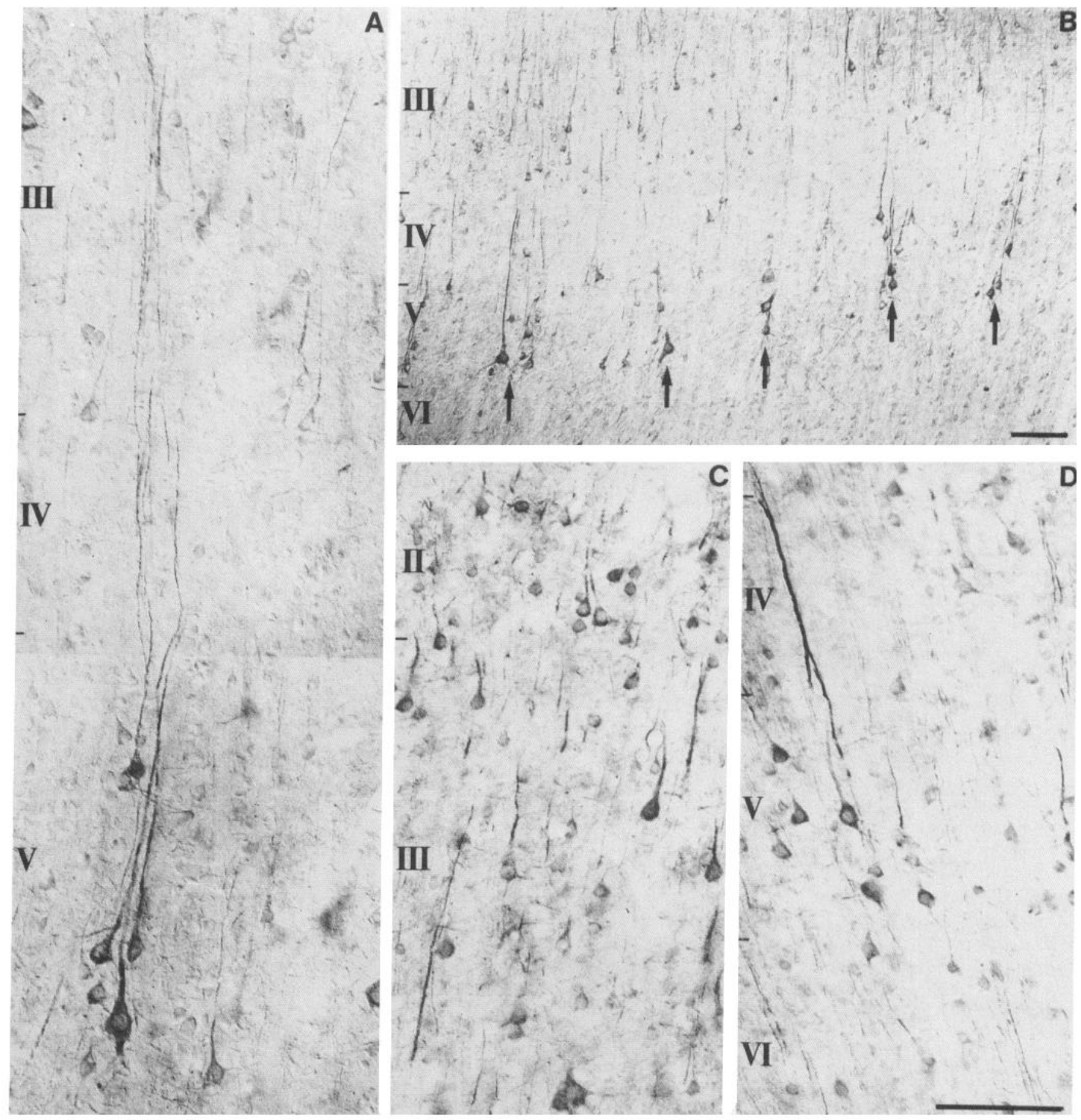

Figure 5. Differential interference contrast photomicrographs through area $3 \mathrm{~b}(A, B)$ and through area $7(C, D)$ showing laminar distribution, density, and pattern of GluR5/6/7 immunoreactivity. In SI, clusters of pyramidal cells in layer V were present (arrows, $B)$, one of which is shown at higher power in $A$. The density and intensity of immunoreactivity were greater in area 7, both in superficial layers $(C)$ and in deeper layers $(D)$, in comparison with SI. Scale bars, $100 \mu \mathrm{m}$ (bar in $D$ is for $A, C$, and $D$ ).

stained ones were present. The results of a cluster analysis of the distribution of darkly stained dendrites in each of the two layers (see Materials and Methods) confirmed the qualitative observations. Dendrites in layer II were considered randomly distributed $(r=1.09)$, while those in layer $\mathrm{V}$ were considered clustered $(r=0.64)$. Each of the layer $\mathrm{V}$ clusters was separated from the others by approximately $150 \mu \mathrm{m}$.

The tangential distribution of dendrites in layers II and V of motor cortex was similar to that described for cingulate cortex
(Fig. $8 C, D$ ). Dendrites were considered randomly distributed in layer II (Fig. 8C; $r=1.08$ ), and were clustered into groups of 3-12 in layer V (arrows, Fig. $8 D ; r=0.59$ ), each separated by approximately $100 \mu \mathrm{m}$.

\section{Ultrastructural localization of GluR5/6/7 subunit immunoreactivity}

Clumps of reaction product appeared diffusely distributed throughout the cytoplasm of both cell somata and dendrites 

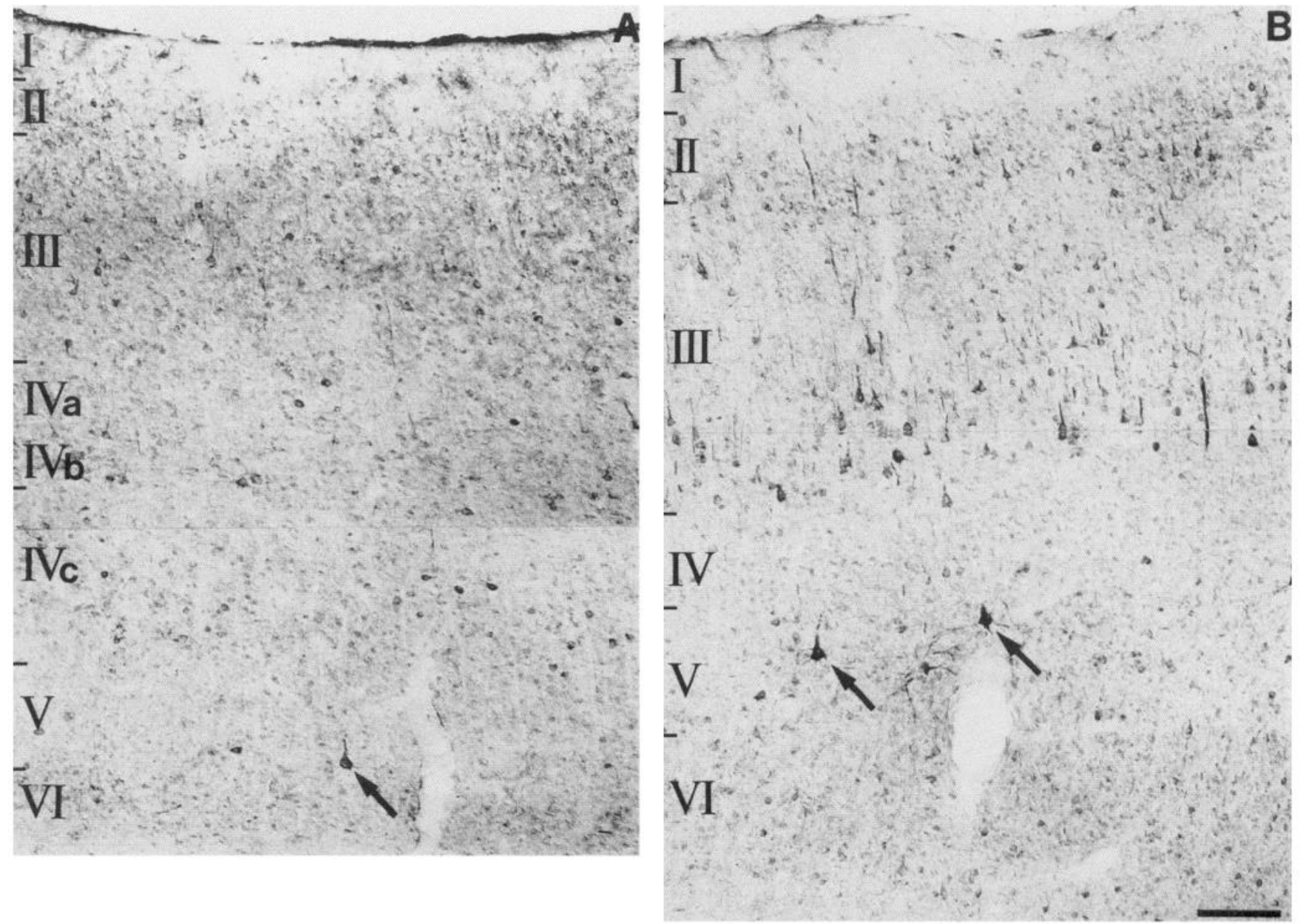

Figure 6. Differential interference contrast photomicrographs through areas $17(A)$ and $18(B)$. Staining was denser in area 18 than in area 17 , which had slightly higher background staining. Arrows $(A, B)$ demarcate relatively larger, more intensely stained cells located at the layer V/VI border in each area. Scale bar, $100 \mu \mathrm{m}$.

(Fig. 9A), although many somata, dendritic shafts, and spines were unlabeled (uns sp, Fig. $9 B$ ). In stained dendrites, reaction product delineated the outer membranes of mitochondria and often appeared associated with microtubules, in addition to the diffuse dendritoplasmic distribution (ds, Fig. 9A). No staining of axons (ax, Fig. 9A) or presynaptic axon terminals (pre, Fig. 9) was observed.

Intense immunocytochemical staining of postsynaptic densities was frequently observed along the lengths of stained dendrites (arrows, Fig. 9). The postsynaptic density labeling was always associated with asymmetrical synapses and presynaptic axon terminals filled with round vesicles (Fig. 9), and was frequently observed on dendritic shafts (ds, Fig. 9A) as well as on dendritic spines. The immunocytochemical labeling at such postsynaptic sites was significantly more intense than that of neighboring nonsynaptic regions of the dendritoplasm. In addition, there were numerous unstained asymmetrical synapses in any given field (asterisk, Fig. 9B). The synaptic clefts were not stained (Fig. 9).

\section{Discussion}

In the present study, the regional, laminar, and cellular distribution of kainate receptor class subunit immunoreactivity was examined in monkey neocortex at the light and electron micro- scopic levels following the generation and subsequent characterization of an $\mathrm{mAb}$ directed against a fusion protein corresponding to an N-terminal portion of the glutamate receptor subunit GluR5, and which recognized subunits GluR5/6/7. The widely variable regional and laminar staining patterns in neocortex suggest that kainate receptors or receptor complexes assembled in part or wholly from GluR 5, -6 , or -7 subunits may play a selective role in mediating the excitatory synaptic transmission associated with particular functional circuits. The interpretation of the results, however, depends on the specificity of the mAb used.

\section{Specificity of $m A B \quad 4 F 5$}

Both Western blot analyses and immunocytochemistry of transfected cells were used in the present study to evaluate the specificity of mAb 4F5. The observation that mAb 4F5 did not recognize the fusion protein derived from the GluR6 construct on Western blots could suggest that mAb 4F5 does not react with GluR6 receptor subunits. However, this is unlikely since mAb 4F5 immunoreactivity was observed in cells transfected with GluR6 or GluR7 receptor subunits. Since the GluR6 construct only partially overlapped that of GluR5, it is therefore likely that the epitope recognized by $\mathrm{mAb} 4 \mathrm{~F} 5$ resides in the region of the GluR5 construct (corresponding to amino acids 
379-518), which was not present in the GluR6 construct. Collectively, the results from the Western blot analyses and from immunocytochemistry of transfected cells are consistent with the interpretation that mAb 4F5 is specific for GluR5, -6, and -7 (the three identified members of the kainate receptor subunit class), but not for GluR 1, -2 , or -3 (the AMPA/kainate receptor subunit class), since the antibody failed to recognize these latter subunits on Western blots or in cells transfected with one of the three AMPA receptor subunits. In situ hybridization studies of rat brain have demonstrated very low levels of GluR5 in neocortex (Bettler et al., 1990); thus, it is likely that the labeling revealed by $\mathrm{mAB} 4 \mathrm{~F} 5$ in monkey cortex is primarily reflecting the presence of GluR6 and GluR7 subunits.

\section{Localization of kainate receptor subunit immunoreactivity}

Cellular specificity. Immunoreactivity resulting from antibody 4F5 appeared restricted to neurons with little or no evidence of neuroglial cell labeling in neocortex. Previous studies suggest, however, that some glial cells possess kainate-sensitive channels (Usowicz et al., 1989; Pruss et al., 1991), and, in the cerebellum, studies have suggested that kainate-binding protein expression is restricted to Bergmann glial cells (Somogyi et al., 1990). It is possible that either cortical glial cells do not possess kainate receptors or they possess ones assembled from other subunits. Alternatively, the levels of GluR5/6/7 subunits in cortical glial cells or unlabeled neurons were too low, thereby preventing detection by immunocytochemistry.

A large number of the neurons possessing GluR5/6/7 immunoreactivity in all areas of neocortex examined appeared to be pyramidal cells, although there were many smaller, labeled somata found throughout the cortical layers that may represent GABAergic interneurons. However, the more detailed doublelabeling immunocytochemical studies of Vickers et al. (1993) have confirmed that subsets of GABAergic interneurons, identified by parvalbumin or calbindin immunoreactivity, only form a small minority of GluR5/6/7-immunoreactive somata. The data suggest that different functional classes of neurons exhibit a remarkable degree of cellular specificity in the complement of glutamate receptor subunits present, which may directly contribute to the establishment of functional properties as well as underlie differential cellular vulnerability to disease or toxicity.

Subcellular localization. At the subcellular level, the immunoprecipitate was mostly restricted to the somatic and dendritic cytoplasm. The intracellular accumulation of reaction product may represent epitope sites associated with various stages of synthesis, transport, assembly, and degradation of receptor subunits, a possibility similar to that which has been proposed previously following the immunocytochemical localization of $\mathrm{GABA}_{\mathrm{A}}$ /benzodiazepine receptors (Richards et al., 1987; Somogyi et al., 1989), a kainate-binding protein (Somogyi et al., 1990), and other AMPA-selective glutamate receptor subunits (Petralia and Wenthold, 1992).

Kainate receptor-mediated fast synaptic transmission has been attributed primarily to postsynaptically localized receptors (for review, see Tsumoto, 1990). However, presynaptic kainate receptors have been described for certain populations of fibers, including primary afferent C-fibers (Agrawal and Evans, 1986; Evans et al., 1987), hippocampal mossy fibers (Represa et al., 1987), and fibers in the cerebellum (Ferkany et al., 1982). Although the precise subunit composition of such presynaptic receptors is unknown, GluR5 subunits have been suggested to represent a major component of the presynaptic kainate recep-

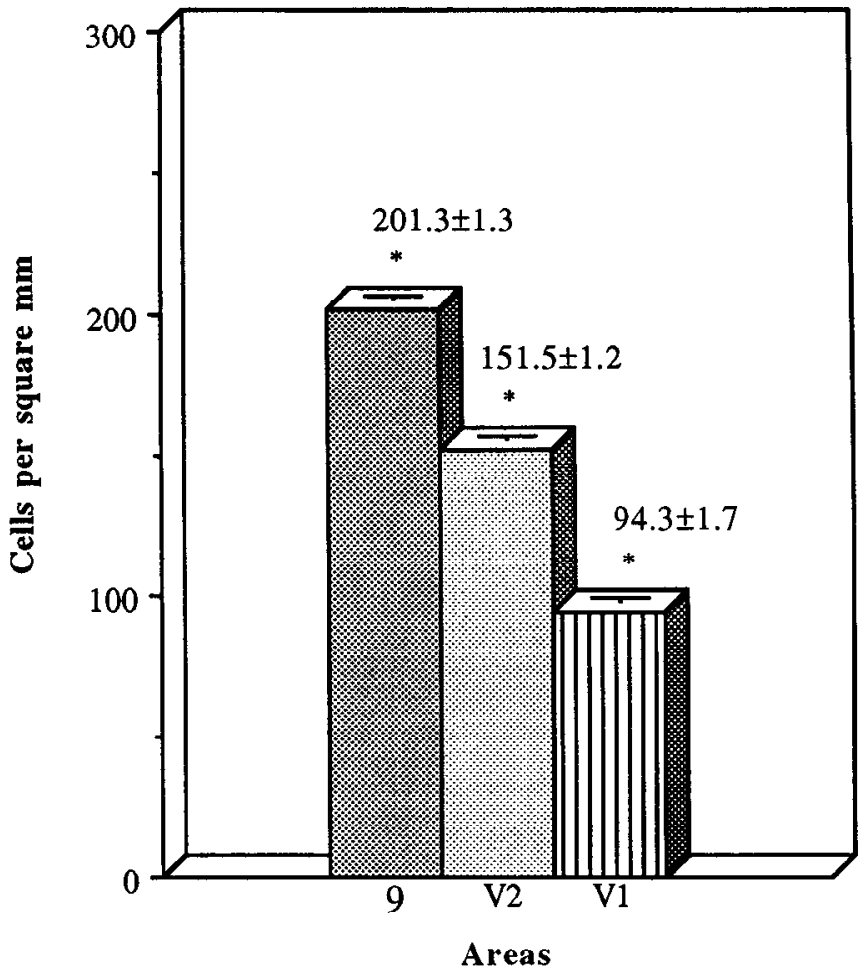

Figure 7. Densities of stained somata from three areas (see Materials and Methods for details). Numbers above each column indicate mean densities and SEM. Asterisks indicate that the density of each area was statistically different from the others (ANOVA, $p<0.001$ ).

tors present on primary afferent C-fibers (Bettler et al., 1990; Huettner, 1990; Sommer et al., 1992). In the present study, no immunoreactivity was found localized to either axons or presynaptic axon terminals, suggesting that in neocortex, GluR5/ 6/7 subunits are present exclusively on postsynaptic cells. Alternatively, presynaptic kainate receptors composed of other subunits may exist in neocortex. However, deafferentation studies in rats suggest that kainate binding sites in striatum are also located postsynaptically (Greenamyre and Young, 1989a); therefore, presynaptic kainate receptors in general may be restricted to certain regions or certain cell populations.

The localization of GluR5/6/7 subunit immunoreactivity to postsynaptic densities was expected, considering the synaptic specificity of excitatory connectivity (reviewed in White, 1989), and is consistent with data from other studies suggesting that functional kainate receptors are synaptically located. Cell fractionation studies, for example, have shown that ${ }^{3} \mathrm{H}$-kainate binding sites are enriched in synaptic membranes (Foster et al., 1981), and physiological studies have suggested that non-NMDA receptors are concentrated at synapses in cultured neurons from cerebral cortex (Jones and Baughman, 1991) and hippocampus (Bekkers and Stevens, 1989). Moreover, electron microscopic, immunocytochemical studies have shown that immunoreactivity for a kainic acid-binding protein labels postsynaptic densities in frog optic tectum (Dechesne et al., 1990), and similar studies in rats have shown immunoreactivity for the AMPA-selective glutamate receptor subunits GluR1, $-2 / 3$, and -4 localized in part to postsynaptic densities in cortex and hippocampus (Blackstone et al., 1992; Petralia and Wenthold, 1992). However, not all postsynaptic densities associated with asymmetrical synapses were immunolabeled with $\mathrm{mAb} 4 \mathrm{~F} 5$. This could indicate that 

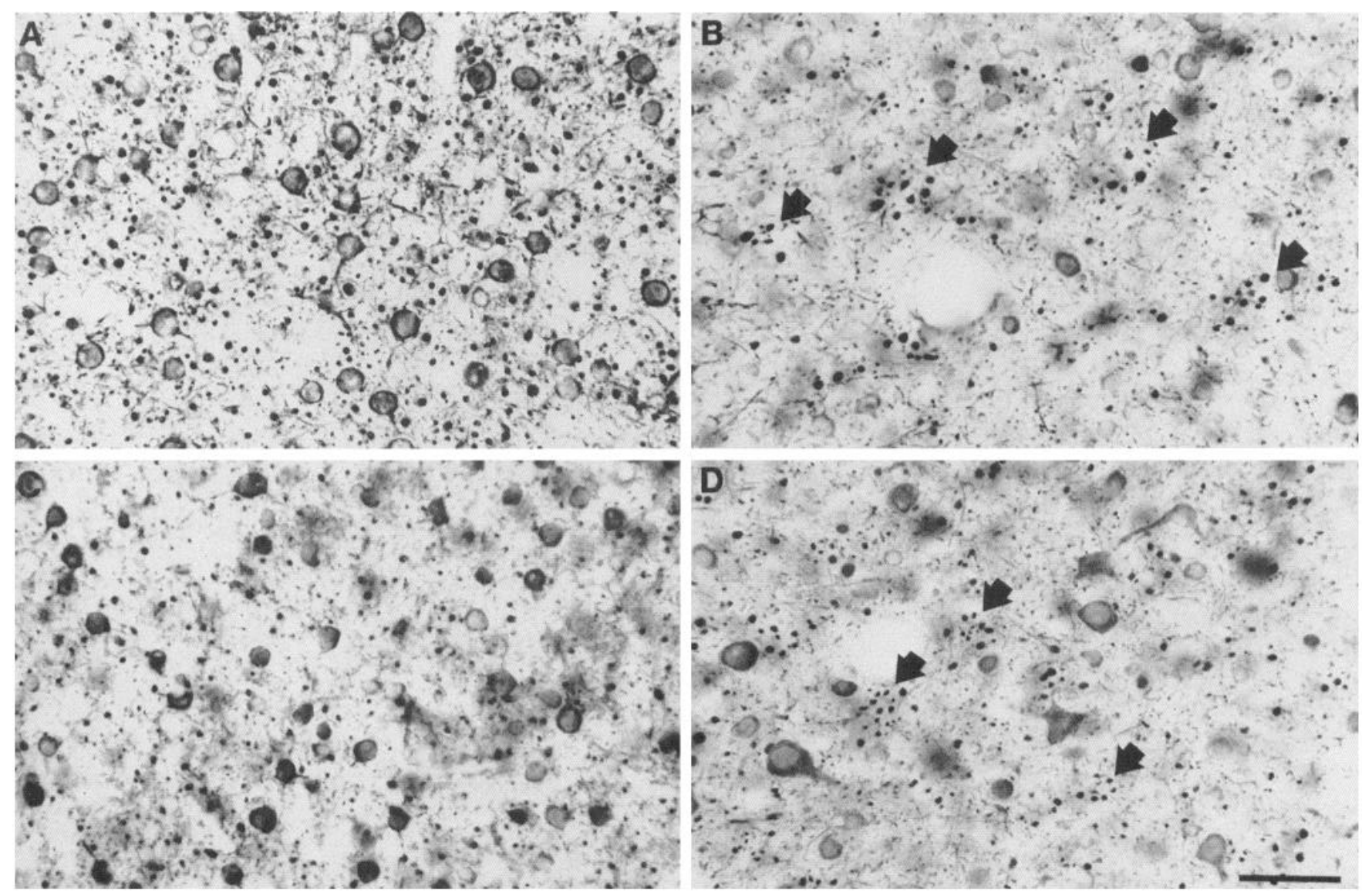

Figure 8. Bright-field photomicrographs of tangential sections taken through anterior cingulate $(A, B)$ and area $4(C, D)$. In each area, intensely stained dendrites cut in cross section appear more evenly distributed in layer II $(A, C)$ in comparison with layer $\mathrm{V}$, in which clusters of intensely stained dendrites were present (arrows, $B, D$ ). See Results for additional details. Scale bar, $100 \mu \mathrm{m}$.

functional kainate receptors composed of GluR5/6/7 subunits are selectively distributed at the cellular and synaptic levels. Nevertheless, the ultrastructural and light microscopic data suggest that there is an extensive cytoplasmic pool of kainate receptor class subunits in the soma and dendrites. Such a large, local reservoir of receptor subunits might allow for dynamic shifts in the synaptic distribution of kainate receptor class subunits without the necessity for increased synthesis or transport over large distances. Local shifts in subunit distribution could lead to changes in the composition of multiple receptor subunit assemblies, functional properties, or relative strengths of subsets of glutamatergic inputs to particular pyramidal neurons.

\section{Functional implications of GluR5/6/7 subunit distribution}

A striking feature of the present results was the marked variability in density and distribution of GluR5/6/7 subunit immunoreactivity across layers and areas of monkey neocortex, which can be summarized as follows: (1) most areas examined possessed numerous stained somata and dendritic processes in layers II, III, and V; layers I, IV, and VI invariably possessed the fewest and/or least intensely stained elements; (2) the presence of bundles of stained dendrites emanating from deeper layers and ascending through more superficial layers, and groupings of intensely stained somata in layer $\mathrm{V}$, were consistent features in many areas; and (3) higher-order association areas (prefrontal, cingulate, and unimodal sensory association areas such as V2 and somatic sensory area 5) appeared more densely stained than primary sensory areas V1 and SI, which was confirmed quantitatively for some areas. Although the precise role of kainate receptors in conveying cortical excitatory synaptic activity remains to be determined, previous pharmacological and physiological approaches attempting to define such a role have been hampered by a lack of antagonists selective enough to discriminate between kainate- and other non-NMDA receptor-mediated responses (Watkins et al., 1991) and by a potential multiplicity of sites to which ${ }^{3} \mathrm{H}$-kainate may bind (Sommer and Seeburg, 1992; see also below). The data described here, however, provide anatomical evidence in primates that GluR5/ $6 / 7$ subunits exhibit a regional, laminar, and cellular specificity that not only supports an important role for kainate receptors in neocortical function, but also contributes to the evolving idea that functional diversity in the ubiquitous excitatory amino acidutilizing axonal systems in neocortex may be achieved in part by the differential association of particular glutamate receptor subunits with specific cortical circuits.

Laminar organization of kainate receptors: relationship to patterns of connectivity. The principal sources of excitatory amino acid-based synaptic activity in the cerebral cortex arise from axons and local axon collaterals of pyramidal neurons and axons of extrinsic thalamic relay neurons (McCormick, 1992). Each of these sets of fibers terminates in layer-specific patterns that show some correlation with the laminar pattern of receptor subunit immunostaining observed.

Layers II and III were among the most densely stained layers 

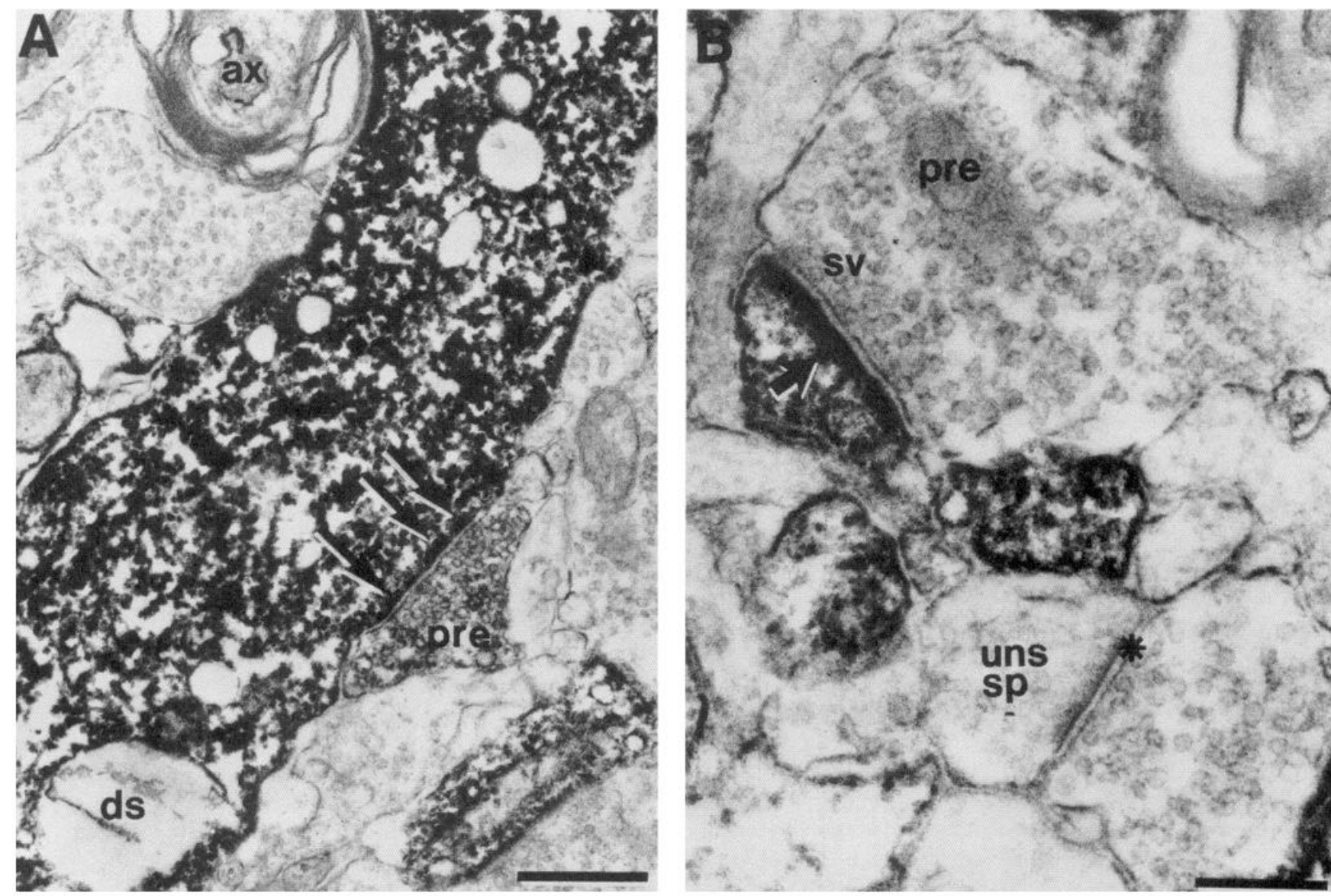

Figure 9. Electron photomicrographs of sections taken through area 9 showing some of the features of the ultrastructural distribution of GluR5/ $6 / 7$ immunoreactivity. $A$, Immunoprecipitation was diffusely distributed throughout the cytoplasm of dendritic shafts $(d s)$. No axons $(a x)$ or presynaptic axon terminals were labeled (pre, $A, B$ ). Arrows indicate an intensely stained postsynaptic density associated with an asymmetrical synapse. $B$ ) Higher-power photomicrograph showing synaptic labeling. Intensely stained postsynaptic density (arrow) associated with an unlabeled presynaptic terminal ( pre) filled with round synaptic vesicles $(s v)$. Asterisk indicates an unlabeled asymmetrical synapse onto a small, unstained dendritic spine (uns $s p$ ). Scale bars: $A, 0.47 \mu \mathrm{m} ; B, 0.26 \mu \mathrm{m}$.

in each of the areas examined. These are the primary, though not exclusive, layers that furnish and receive the major corticocortical and callosal projections (Innocenti, 1986; Jones, 1986). In addition, many cortical areas possess intrinsic, horizontally oriented axon collaterals whose main terminal ramifications are in layers II/III and V (e.g., Huntley and Jones, 1991; Gilbert, 1992). Physiological studies support the role of non-NMDA receptors in the generation of postsynaptic potentials following the stimulation of intracortical pathways (Jones and Baughman, 1988; Shirokawa et al., 1989; Thomson, 1990; Kawaguchi, 1992), although the relative contributions of the AMPA and kainate receptor subtypes are not known. The dense GluR5/6/7 subunit immunostaining in the superficial layers and in layer $\mathrm{V}$ suggests that in monkey cortex, kainate receptors may mediate a large share of the activity conveyed by corticocortical and callosal axons and by local pyramidal cell axon collaterals.

The correspondence between receptor subunit staining and thalamocortical projections is less clear. There was little staining in the layers of $\mathrm{V} 1$ that receive the majority of geniculocortical axon terminations, which correspond to layers I, IVA, IVC, and VI (Hubel and Wiesel, 1972). By contrast, in regions such as motor cortex and areas 1, 2, 5, and 7, the main thalamic terminations are found predominately in layer III (Jones and Burton, 1976; Jones et al., 1979), which was rich in receptor subunit immunoreactivity. In other regions, such as prefrontal cortex and area 3 , the terminations of thalamocortical axons coincide in part with deep layer III (Jones et al., 1979; Giguere and Goldman-Rakic, 1988), which in both areas was rich in receptor subunit-stained somata and apical dendrites, and in part with layer IV, in which few stained cell somata were present but in which many labeled dendrites were present. These data suggest that the role of GluR 5/6/7 subunits in thalamocortical information processing may be regionally specific, and limited to a discrete subpopulation of thalamorecipient cells.

Morphological studies indicate that many layer III neurons possess basilar dendrites that descend into layer IV, and an apical dendrite that reaches layer I (Feldman, 1984), making such cells likely targets for receiving corticocortical and thalamic connections in both granular and supragranular layers (Sloper and Powell, 1979; Hendry and Jones, 1983). In our material, however, most basilar dendrites of immunoreactive layer III cells were not extensively stained and their ascending apical dendrites, which appeared well stained in layers II and III, could not be followed into layer I. In addition, in some areas the stained dendritic bundles furnished by infragranular pyramidal cells coincided precisely with layer IV and the deeper half of layer III, but could not be followed more superficially. One explanation for such a staining pattern may be that single cells 
in monkey cortex parcellate GluR5/6/7 subunits to coincide selectively with the terminations of functionally distinct components of corticocortical and thalamocortical projections that are found in different layers, since studies have shown that the activities of functionally distinct inputs impinging onto single cells within an avian forebrain song nucleus are mediated by different glutamate receptor subtypes (Mooney and Konishi, 1991). Corticocortical inputs to layer I of sensory cortex, for example, are thought to comprise part of the so-called "feedback" projections and may differ functionally from "feedforward" corticocortical projections that in general target middle layers (Rockland and Pandya, 1979; Felleman and Van Essen, 1991). Likewise, in SI of monkeys, thalamocortical relay cells whose axons terminate in layer I are calbindin immunopositive and are likely to receive predominately spinothalamic terminations while those whose axons target middle layers are mostly parvalbumin immunopositive and receive primarily lemniscal or principal trigeminal inputs (Rausell and Jones, 1991; Rausell et al., 1992). It could also be possible that distal dendrites were incompletely stained, since these tend to be of the smallest caliber and therefore may possess too low a concentration of antigen to be detected. In deeper layers, however, very smallcaliber immunoreactive dendrites were frequently observed. Thus, although incomplete staining does not seem as likely an explanation, further analysis with more sensitive techniques will be required to determine this.

The laminar pattern of GluR5/6/7 immunostaining differs somewhat from the laminar pattern of ${ }^{3} \mathrm{H}$-kainic acid binding sites previously reported. Autoradiographic studies in the cortex of rats, monkeys, and humans indicate that such binding sites are present throughout the cortical layers, although the greatest concentrations are found primarily in layers I and V/VI (Monaghan and Cotman, 1982; Unnerstall and Wamsley, 1983; Greenamyre et al., 1985; Cross et al., 1987; Jansen et al., 1989; Albin et al., 1991). The discrepancy may reflect a potentially larger selection of receptor sites to which ${ }^{3} \mathrm{H}$-kainate may be binding, since other kainate-binding proteins such as KA2, as well as the AMPA-selective receptor subunits GluR1-GluR4, can also bind kainate and have a widespread distribution in rat neocortex (Bettler et al., 1990, 1992; Boulter et al., 1990; Keinanen et al., 1990; Sommer et al., 1990; Pellegrini-Giampietro et al., 1991; Herb et al., 1992; Petralia and Wenthold, 1992; Sun et al., 1992).

Columnar organization of kainate receptors: dendritic bundles. Dendritic bundles in many areas of cortex have been described previously in histological studies of cortical cellular organization (von Bonin and Mehler, 1971; Fleischhauer et al., 1972; Peters and Walsh, 1972). It is not known, however, whether every dendrite contributing to a bundle was stained, or whether only a subpopulation of dendrites within a larger bundle was stained. Furthermore, not all areas in monkey cortex that possess dendritic bundles contained ones identified by receptor subunit immunostaining. For example, no stained bundles were observed in area 17 of the kind described by immunostaining for MAP2 (Peters and Sethares, 1991a,b).

From a functional standpoint, the aggregations of receptor subunit-stained dendrites into discrete bundles may correspond in part to targets of the discrete, focused aggregations of corticocortical, callosal, and thalamocortical axon terminations that form the basis for clusters of cells with common input/output properties (reviewed in Jones, 1981). It has been suggested previously that dendritic bundles that emanate from clusters of layer $\mathrm{V}$ pyramidal cells form the core of a set of larger pyramidal cell modules that represent anatomically defined, functional units in monkey visual cortex (Peters and Sethares, 1991b). The observations from the present study raise the possibility that in some areas, similar modules may exist in which aggregates of layer $\mathrm{V}$ cells share, in part, a common excitatory amino acidreceptor profile, which may in turn underlie the similarity in functional properties among groups of cells comprising functional columns defined on physiological grounds (Mountcastle, 1957; Hubel and Wiesel, 1963).

Regional organization of kainate receptors: implications for kainate receptor-mediated toxicity. The present results indicate that GluR5/6/7 subunit immunoreactivity appears to be more dense in higher-order association areas of the frontal and parietal lobes in comparison to the primary sensory areas SI and V1. These qualitative observations were confirmed quantitatively by comparing the densities of stained somata in areas $9, \mathrm{~V} 1$, and V2 (see Fig. 7). The data raise the possibility that the functions of higher-order association areas may be particularly vulnerable to kainate receptor-mediated toxicity. For example, patients suffering from ingestion of domoic acid-a potent glutamate analog that binds to GluR5 with an affinity greater than that of kainate (Sommer et al., 1992)-can display difficulties in visuospatial memory tasks involving delayed recall (Teitelbaum et al., 1990), a function attributed in part to areas of the prefrontal cortex (Goldman-Rakic, 1987). Moreover, neuropathological examination of the brains from such patients (Teitelbaum et al., 1990) reveals marked cell death in a variety of brain regions, including parts of the prefrontal cortex and in the thalamic mediodorsal nucleus, which projects heavily to prefrontal cortex (Giguere and Goldman-Rakic, 1988).

The dense GluR5/6/7 subunit immunoreactivity in prefrontal and other association areas may also indicate an involvement of such subunits in other diseases thought to affect higher cortical function, such as schizophrenia and Alzheimer's disease (AD). Dysfunctions in glutamatergic transmission, for example, have been reported in the brains of schizophrenics (Deakin et al., 1989), which may involve kainate receptors, since increases in the number of ${ }^{3} \mathrm{H}$-kainic acid binding sites have been described in the prefrontal cortices of schizophrenic patients (Nishikawa et al., 1983). In addition, the pyramidal cells within layers III and $\mathrm{V}$ of association cortex that are likely to provide corticocortical interconnections have been identified as particularly vulnerable in AD (Pearson et al., 1985; Lewis et al., 1987; reviewed in Morrison et al., 1990). The morphological, laminar, and regional characteristics of the GluR5/6/7-immunoreactive neurons described correlate with those of the vulnerable neurons in $\mathrm{AD}$, raising the possibility that, in humans, a kainate receptor-mediated excitotoxic mechanism might preferentially affect the same population of pyramidal cells that have been implicated in AD and other dementing illnesses. Kainate and AMPA receptor activation can stimulate $\mathrm{Ca}^{2+}$ influx (Murphy and Miller, 1989; Iino et al., 1990; Hollmann et al., 1991; Gasic and Heinemann, 1992; Muller et al., 1992), which in turn may underlie chronic neuroexcitotoxicity and degeneration (Coyle et al., 1981; Koh et al., 1990). Despite a long-standing implication of glutamate receptor-mediated excitotoxicity in ischemia (Choi, 1988) and in certain neurodegenerative diseases (Greenamyre and Young, 1989b), it has been extremely difficult to incorporate a given neuron's glutamate receptor profile into a more comprehensive profile of the characteristics that might be causally linked to the vulnerability of a neuron or class of neurons in a 
given disease. The production of glutamate receptor subunit or subunit class-specific antisera has now made it possible to begin the process of developing comprehensive glutamate receptor profiles of identified neurons that can be linked to morphology, connectivity, function, and vulnerability as well as lead to an understanding of excitatory circuits that more accurately reflects their functional complexity and heterogeneity.

\section{References}

Agrawal SG, Evans RH (1986) The primary afferent depolarizing action of kainate in the rat. Br J Pharmacol 87:345-355.

Albin RL, Sakurai SY, Makowiec RL, Higgins DS, Young AB, Penney JB (1991) Excitatory amino acid, GABA-A, and GABA-B binding sites in human striate cortex. Cereb Cortex 1:499-509.

Barbaresi PB, Fabri M, Conti F, Manzoni T (1987) D-[ $\left.{ }^{3} \mathrm{H}\right]$ aspartate retrograde labelling of callosal and association neurones of somatosensory areas I and II of cats. J Comp Neurol 263:159-178.

Baughman RW, Gilbert CD (1981) Aspartate and glutamate as possible neurotransmitters in the visual cortex. J Neurosci 1:427-439.

Bekkers JM, Stevens CF (1989) NMDA and non-NMDA receptors are co-localized at individual excitatory synapses in cultured rat hippocampus. Nature 341:230-233.

Bettler B, Boulter J, Hermans-Borgmeyer I, O'Shea-Greenfield A, Deneris ES, Moll C, Borgmeyer U, Hollmann M, Heinemann S (1990) Cloning of a novel glutamate receptor subunit, GluR5: expression in the nervous system during development. Neuron 5:583-595.

Bettler B, Egebjerg J, Sharma G, Pecht G, I Iermans-Borgmeyer I, Moll C, Stevens CF, Heinemann S (1992) Cloning of a putative glutamate receptor: a low affinity kainate-binding subunit. Neuron 8:257-265.

Blackstone CD, Moss SJ, Martin LJ, Levey AI, Price DL, Huganir RL (1992) Biochemical characterization and localization of a non- $N$ methyl-D-aspartate glutamate receptor in rat brain. J Neurochem 58 : $1118-1126$.

Boulter J, Hollmann M, O'Shea-Greenfield A, Hartley M, Deneris E, Maron C, Heinemann S (1990) Molecular cloning and functional expression of glutamate receptor subunit genes. Science 249:10331037.

Brodmann K (1905) Beitrage zur histolgischen Lokalisation der Grosshirnrinde. III. Dritte Mitteilung die Rindenfelder der niederen Affen. J Psychol Neurol 4:177-226.

Chen C, Okayama H (1992) High-efficiency transformation of mammalian cells by plasmid DNA. Mol Cell Biol 2745-2752.

Choi DW (1988) Glutamate neurotoxicity and diseases of the nervous system. Neuron 1:623-634.

Collingridge GL, Singer W (1990) Excitatory amino acid receptors and synaptic plasticity. Trends Pharmacol Sci 11:290-296.

Conti F, Rustioni A, Petrusz P, Towle AC (1987) Glutamate-positive neurons in the somatic sensory cortex of rats and monkeys. $J$ Neurosci 7:1887-1901.

Coyle JT, Bird SJ, Evans RH, Gulley RL, Nadler JV, Nicklas WJ, OIney JW (1981) Excitatory amino acid neurotoxins: selectivity, specificity, and mechanisms of action. Neurosci Res Prog Bull 19:331-427.

Cross AJ, Skan WJ, Slater P, Mitchell IJ, Crossman AR (1987) Autoradiographic analysis of $\left[{ }^{3} \mathrm{H}\right]$ kainic acid binding in primate brain. J Recept Res 7:775-797.

Deakin JFW, Slater P, Simpson MDC, Gilchrist AC, Skan WJ, Royston MC, Reynolds GP, Cross AJ (1989) Frontal cortical and left temporal glutamatergic dysfunction in schizophrenia. $J$ Neurochem 52 : 1781-1786.

Dechesne CJ, Oberdorfer MD, Hampson DR, Wheaton KD, Nazarali AJ, Goping G, Wenthold RJ (1990) Distribution of a putative kainic acid receptor in the frog central nervous system determined with monoclonal and polyclonal antibodies: evidence for synaptic and extrasynaptic localization. J Neurosci 10:479-490.

DeFelipe J, Fairén A (1992) A simple and reliable method for correlative light and electron microscopic studies. J Histochem Cytochem, in press.

DeFelipe J, Conti F, Van Eyck SL, Manzoni T (1988) Demonstration of glutamate-positive axon terminals forming asymmetric synapses in cat neocortex. Brain Res 455:162-165.

Dieckmann CL, Tzagoloff A (1985) Assembly of the mitochondrial membrane system. J Biol Chem 260:1513-1520.

Dori I, Dinopoulos A, Cavanagh ME, Parnavelas JG (1992) Propor- tion of glutamate- and aspartate-immunoreactive neurons in the efferent pathways of the rat visual cortex varies according to the target. J Comp Neurol 319:191-204.

Egebjerg J, Bettler B, Hermans-Borgmeyer K, Heinemann S (1991) Cloning of a cDNA for a glutamate receptor subunit activated by kainate but not AMPA. Nature 351:745-748.

Evans RH, Evans SJ, Pook PC, Sunter DC (1987) A comparison of excitatory amino acid antagonists acting at primary afferent $C$ fibers and motoneurones of the isolated spinal cord of the rat. $\mathrm{Br} \mathrm{J}$ Pharmacol 91:531-537.

Feldman ML (1984) Morphology of the neocortical pyramidal neuron. In: The cerebral cortex, Vol 5 (Jones EG, Peters A, eds), pp 123-200. New York: Plenum.

Felleman DJ, Van Essen DC (1991) Distributed hierarchical processing in the primate cerebral cortex. Cereb Cortex $1: 1-47$.

Fcrkany JW, Zaczck R, Coylc JT (1982) Kainic acid stimulates excitatory amino acid neurotransmitters release at presynaptic receptors. Nature 298:757-759.

Fleischhauer K, Petsche H, Wittkowski W (1972) Vertical bundles of dendrites in the neocortex. Z Anat Entwicklungsgesch 136:213-223.

Foster AC, Mena EE, Monaghan DT, Cotman CW (1981) Synaptic localization of kainic acid binding sites. Nature 289:73-75.

Gasic GP, Heinemann S (1992) Determinants of the calcium permeation of ligand-gated cation channels. Curr Opin Cell Biol 4:670677.

Giguere M, Goldman-Rakic PS (1988) Mediodorsal nucleus: areal, laminar, and tangential distribution of afferents and efferents in the frontal lobe of rhesus monkeys. J Comp Neurol 277:195-213.

Gilbert CD (1992) Horizontal integration and cortical dynamics. Neuron $9: 1-13$.

Giuffrida R, Rustioni A (1989) Glutamate and aspartate immunoreactivity in cortico-cortico neurons of the sensorimotor cortex of rats. Exp Brain Res 74:41-46.

Goldman-Rakic PS (1987) Circuitry of the prefrontal cortex and the regulation of behavior by representational knowledge. In: Handbook of physiology, Vol 5 (Plum F, Mountcastle V, eds), pp 373-417. Bethesda, MD: American Physiological Society.

Gray EG (1969) Electron microscopy of excitatory and inhibitory synapses: a brief review. Prog Brain Res 31:141-155.

Greenamyre JT, Young AB (1989a) Synaptic localization of striatal NMDA, quisqualate and kainate receptors. Neurosci Lett 101:133137.

Greenamyre JT, Young AB (1989b) Excitatory amino acids and Alzheimer's disease. Neurobiol Aging 10:593-602.

Greenamyre JT, Olson JMM, Penney J, Young AB (1985) Autoradiographic characterization of $N$-methyl-D-aspartate-, quisqualateand kainate-sensitive glutamate binding sites. J Pharmacol Exp Ther 233:254-263.

Gregor P, Mano I, Maoz I, Mckeown M, Teichberg VI (1989) Molecular structure of the chick cerebellar kainate-binding subunit of a putative glutamate receptor. Nature 342:689-692.

Hendry SHC, Jones EG (1983) Thalamic inputs to identified commissural neurons in the monkey somatic sensory cortex. J Neurocytol 12:299-316.

Herb A, Burnashev N, Werner P, Sakmann B, Wisden W, Seeburg P (1992) The KA-2 subunit of excitatory amino acid receptors shows widespread expression in brain and forms ion channels with distantly related subunits. Neuron 8:775-785.

Hollmann M, O'Shea-Greenfield A, Rogers SW, Heinemann S (1989) Cloning by functional expression of a member of the glutamate receptor family. Nature 342:643-648.

Hollmann M, Hartley M, Heinemann S (1991) Calcium permeability of KA-AMPA-gated glutamate receptor channels: dependence on subunit composition. Science 252:851-853.

Hubel DH, Wiesel TN (1963) Shape and arrangement of columns in cat's striate cortex. J Physiol (Lond) 165:559-568.

Hubel DH, Wiesel TN (1972) Laminar and columnar distribution of geniculo-cortical fibers in the macaque monkey. J Comp Neurol 146: $421-450$

Huettner JE (1990) Glutamate receptor channels in rat DRG neurons: activation by kainate and quisqualate and blockade of desensitization by Con A. Neuron 5:255-266.

Huntley GW, Jones EG (1991) Relationship of intrinsic connections to forelimb movement representations in monkey motor cortex: a correlative anatomic and physiological study. J Neurophysiol 66:390413. 
Iino M, Ozowa S, Tsuzuki K (1990) Permeation of calcium through excitatory amino acid receptor channcls in cultured rat hippocampal neurones. J Physiol (Lond) 424:151-165.

Innocenti GM (1986) General organization of callosal connections in the cerebral cortex. In: The cerebral cortex, Vol 5, Sensory-motor areas and aspects of cortical connectivity (Jones EG, Peters A, eds), pp 291-354. New York: Plenum.

Jansen KLR, Faull RLM, Dragunow M (1989) Excitatory amino acid receptors in the human cerebral cortex: a quantitative autoradiographic study comparing the distributions of $\left[{ }^{3} \mathrm{H}\right] \mathrm{TCP},\left[{ }^{3} \mathrm{H}\right]$ glycine, L- $\left[{ }^{3} \mathrm{H}\right]$ glutamate, $\left[{ }^{3} \mathrm{H}\right] \mathrm{AMPA}$ and $\left[{ }^{3} \mathrm{H}\right]$ kainic acid binding sites. Neuroscience 32:587-607.

Johnson RR, Burkhalter A (1992) Evidence for excitatory amino acid neurotransmitters in the geniculo-cortical pathway and local projections within rat primary visual cortex. Exp Brain Res 89:20-30.

Joncs EG (1981) Anatomy of cerebral cortex: columnar input-output organization. In: The organization of the cerebral cortex (Schmitt FO, Worden FG, Adelman G, Dennis SG, eds), pp 198-235. Cambridge, MA: MIT Press

Jones EG (1986) Connectivity of the primate sensory-motor cortex. In: The cerebral cortex, Vol 5, Sensory-motor areas and aspects of cortical connectivity (Jones EG, Peters A, eds), pp 113-184. New York: Plenum.

Jones EG, Burton H (1976) Areal differences in the laminar distribution of thalamic afferents in cortical fields of the insular, parietal and temporal regions of primates. J Comp Neurol 168:197-248.

Jones EG, Wise SP, Coulter JD (1979) Differential thalamic relationships of sensory-motor and parietal cortical fields in monkeys. J Comp Neurol 183:833-883.

Jones KA, Baughman RW (1988) NMDA- and non-NMDA-receptor components of excitatory synaptic potentials recorded from cells in layer $V$ of rat visual cortex. J Neurosci 8:3522-3534.

Jones KA, Baughman KW (1991) Both NMDA and non-NMDA subtypes of glutamate receptors are concentrated at synapses on cerebral cortical neurons in culture. Neuron 7:593-603.

Kawaguchi Y (1992) Receptor subtypes involved in callosally-induced postsynaptic potentials in rat frontal agranular cortex in vitro. Exp Brain Res 88:33-40.

Keinanen K, Wisden W, Sommer B, Werner P, Herb A, Verdoorn TA, Sakmann B, Seeburg PH (1990) A family of AMPA-selective glutamate receptors. Science 249:556-560.

Kisvarday ZF, Cowey A, Smith AD, Somogyi P (1989) Interlaminar and lateral excitatory amino acid connections in the striate cortex of monkey. J Neurosci 9:667-682.

Koh J-Y, Goldberg MP, Hartley DM, Choi DW (1990) Non-NMDA receptor-mediated neurotoxicity in cortical culture. J Neurosci 10: 693-705.

LeVay S (1973) Synaptic patterns in the visual cortex of the cat and monkey: electron microscopy of Golgi preparations. J Comp Neurol 140:53-86.

Lewis DA, Campbell MC, Terry RD, Morrison JH (1987) Laminar and regional distributions of neurofibrillary tangles and neuritic plaques in Alzheimer's disease: a quantitative study of visual and auditory cortices. J Neurosci 7:1799-1808.

Lowry OH, Rosenbrough NJ, Farr AL, Randall RJ (1951) Protein measurement with the folin phenol reagent. J Biol Chem 193:265275

Manzoni T, Barbaresi P, Fabri M (1986) D- $\left[{ }^{3} \mathrm{H}\right]$ aspartate retrograde labelling of association neurones in area SI of the cat. Neurosci Lett 67:175-180

Mayer ML, Westbrook GL (1987) The physiology of excitatory amino acids in the vertebrate central nervous system. Prog Neurobiol 28: 197-276.

McCormick DA (1992) Neurotransmitter actions in the thalamus and cerebral cortex and their role in neuromodulation of thalamocortical activity. Prog Neurohiol 39:337-388

Meldrum B, Garthwaite J (1991) Excitatory amino acid neurotoxicity and neurodegenerative disease. Trends Pharmacol Sci 11:54-61.

Monaghan DT, Cotman CW (1982) The distribution of $\left[{ }^{3} \mathrm{H}\right]$ kainic acid binding sites in rat $\mathrm{CNS}$ as determined by autoradiography. Brain Res 252:91-100.

Montero VM (1990) Quantitative immunogold analysis reveals high glutamate levels in synaptic terminals of retino-geniculate, corticogeniculate, and geniculo-cortical axons in the cat. Vis Neurosci 4:437443

Mooney R, Konishi M (1991) Two distinct inputs to an avian song nucleus activate different glutamate receptor subtypes on individual neurons. Proc Natl Acad Sci USA 88:4075-4079.

Morrison JH, Magistretti PJ, Benoit R, Bloom FE (1984) The distribution and morphological characteristics of the intracortical VIP. positive cell: an immunohistochemical analysis. Brain Res 292:269_ 282.

Morrison JH, Hof PR, Campbell MJ, De Lima AD, Voigt T, Bouras C, Cox K, Young WG (1990) Cellular pathology in Alzheimer's disease: implications for corticocortical disconnection and differential vulnerability. In: Imaging, cerebral topography and Alzheimer's disease (Rapoport SI, Petit H, Leys D, Christen Y, eds), pp 19-40. New York: Springer.

Mountcastle VB (1957) Modality and topographic properties of single neurons of the cat's somatic sensory cortex. J Neurophysiol 20:408434

Muller T, Moller T, Berger T, Schnitzer J, Kettenmann H (1992) Calcium entry through kainate receptors and resulting potassium-channe blockade in Bergmann glial cells. Science 256:1563-1566.

Murphy SN, Miller RJ (1989) Regulation of $\mathrm{Ca}^{++}$influx into striatal neurons by kainic acid. J Pharmacol Exp Ther 249:184-293.

Nakanishi N, Shneider NA, Axel R (1990) A family of glutamate receptor genes: evidence for the formation of heteromultimeric receptors with distinct channel properties. Neuron 5:569-581.

Nishikawa T, Takashima M, Toru M (1983) Increased ${ }^{3} \mathrm{H}-$ kainic acid binding in the prefrontal cortex in schizophrenia. Neurosci Lett 40: $245-250$.

Ottersen OP, Storm-Mnthisen J (1984) Glutamate- and GABA-containing neurons in the mouse and rat brain, as demonstrated with a new immunocytochemical technique. J Comp Neurol 229:374-392.

Pcarson RCA, Esiri MM, Hiorns RW, Wilcock GK, Powell TPS (1985) Anatomical correlates of the distribution of the pathological changes in the neocortex in Alzheimer's disease. Proc Natl Acad Sci USA 82: $4531-4534$.

Pellegrini-Giampietro DE, Bennett MVL, Zukin RS (1991) Differential expression of three glutamate receptor genes in developing rat brain: an in situ hybridization study. Proc Natl Acad Sci USA 88 $4157-4161$.

Peters A, Sethares C (1991a) Layer IVA of rhesus monkey primary visual cortex. Cereb Cortex 1:445-462.

Peters A, Sethares C (1991b) Organization of pyramidal neurons in area 17 of monkey visual cortex. J Comp Neurol 306:1-23.

Peters A, Walsh TM (1972) A study of the organization of apical dendrites in the somatic sensory cortex of the rat. J Comp Neurol 144:253-268.

Petralia RS, Wenthold RJ (1992) Light and electron immunocytochemical localization of AMPA-selective glutamate receptors in the rat brain. J Comp Neurol 318:329-354.

Pruss RM, Akeson RL, Racke MM, Wilburn JL (1991) Agonist-activated cobalt uptake identifies divalent cation-permeable kainate receptors on neurons and glial cells. Neuron 7:509-518.

Rausell E, Jones EG (1991) Chemically distinct compartments of the thalamic VPM nucleus in monkeys relay principal and spinal trigeminal pathways to different layers of the somatosensory cortex. J Neurosci 11:226-237.

Rausell E, Bae CS, Viñuela A, Huntley GW, Jones EG (1992) Calbindin and parvalbumin cells in monkey VPL thalamic nucleus: distribution, laminar cortical projections and relations to spinothalamic terminations. J Neurosci 12:4088-4111.

Represa A, Tremblay E, Ben-Ari Y (1987) Kainate binding sites in the hippocampal mossy fibers: localization and plasticity. Neuroscience 20:739-748.

Richards JG, Schoch P, Haring P, Takacs B, Mohler H (1987) Resolving $\mathrm{GABA}_{\mathrm{A}}$ /benzodiazepine receptors: cellular and subcellular localization in the CNS with monoclonal antibodies. J Neurosci $7: 1866-1886$

Rockland KS, Pandya DN (1979) I aminar origins and terminations of cortical connections of the occipital lobe in the rhesus monkey. Brain Res 179:3-20.

Rogers SW, Hughes TE, Hollmann M, Casic GP, Deneris ES, Heinemann S (1991) The characterization and localization of the glutamate receptor subunit GluR1 in the rat brain. J Neurosci 11:27132724.

Rogers SW, Mandelzys A, Deneris ES, Cooper E, Heinemann S (1992) The expression of nicotinic acetylcholine receptors by $\mathrm{PC} 12$ cells treated with NGF. J Neurosci 12:461 1-4623.

Saint Marie RL, Peters A (1985) The morphology and synaptic con- 
nections of spiny stellate neurons in monkey visual cortex (area 17): a Golgi-electron microscopic study. J Comp Neurol 226:213-235.

Sakimura K, Morita T, Kushiya E, Mishina M (1992) Primary structure and expression of the gamma-2 subunit of the glutamate receptor channel selective for kainate. Neuron 8:267-274.

Shatz CJ (1990) Impulse activity and the patterning of connections during CNS development. Neuron 5:745-756.

Shirokawa T, Nishigiori A, Kimura F, Tsumoto T (1989) Actions of excitatory amino acid antagonists on synaptic potentials of layer II/ III neurons of the cat's visual cortex. Exp Brain Res 78:489-500.

Sloper JJ, Powell TPS (1979) An experimental electron microscopic study of afferent connections to the primate motor and somatic sensory cortices. Philos Trans R Soc Lond [Biol] 285:199-226.

Sommer B, Seeburg PH (1992) Glutamate receptor channels: novel properties and new clones. Trends Pharmacol Sci 13:291-296

Sommer B, Keinanen K, Verdoorn TA, Wisden W, Burnashev N, Herb A, Kohler M, Tamaki T, Sakmann B, Seeburg PH (1990) Flip and Flop: a cell-specific functional switch in glutamate-operated channels of the CNS. Science 249:1580-1585.

Sommer B, Burnashev N, Verdoorn TA, Keinanen K, Sakmann B, Seeburg PH (1992) A glutamate receptor channel with high affinity for domoate and kainate. EMBO J 11:1651-1656.

Somogyi P, Takagi H, Richards JG, Mohler H (1989) Subcellular localization of benzodiazepine/GABA receptors in the cerebellum of rat, cat, and monkey using monoclonal antibodies. J Neurosci 9:2197-2209.

Somogyi P, Eshhar N, Teichberg VI, Roberts JDB (1990) Subcellular localization of a putative kainate receptor in Bergmann glial cells using a monoclonal antibody in the chick and fish cerebellar cortex. Neuroscience 35:9-30.

Streit P (1984) Glutamate and aspartate as transmitter candidates for systems of the cerebral cortex. In: Cerebral cortex, Vol 2, Functional properties of cortical cells (Jones EG, Peters A, eds), pp 119-172. New York: Plenum.

Sun W, Ferrer-Montiel AV, Schinder AF, McPherson JP, Evans GA, Montal M (1992) Molecular cloning, chromosomal mapping, and functional expression of human brain glutamate receptors. Proc Natl Acad Sci USA 89:1443-1447.

Teitelbaum JS, Zatorre RJ, Carpenter S, Gendron D, Evans AC, Gjedde A, Cashman NR (1990) Neurologic sequelae of domoic acid intox- ication due to the ingestion of contaminated mussels. N Engl J Med 322:1781-1787.

Thomson AM (1990) Augmentation by glycine and blockade by 6-cyano-7-nitroquinoxaline-2,3-dione (CNQX) of responses to excitatory amino acids in slices of rat neocortex. Neuroscience 39:6979.

Tsumoto T (1990) Excitatory amino acid transmitters and their receptors in neural circuits of the cerebral cortex. Neurosci Res 9:79102.

Unnerstall JR, Wamsley JK (1983) Autoradiographic localization of high affinity $\left[{ }^{3} \mathrm{H}\right] \mathrm{kainic}$ acid binding sites in the rat forebrain. Eur $\mathrm{J}$ Pharmacol 86:361-371.

Usowicz MM, Gallo V, Cull-Candy SG (1989) Multiple conductance channels in type- 2 cerebellar astrocytes activated by excitatory amino acids. Nature 339:380-383.

Vickers JC, Huntley GW, Edwards AM, Moran T, Rogers SW, Heinemann SF, Morrison JH (1993) Quantitative localization of AMPA kainate and kainate glutamate receptor subunit immunoreactivity in neurochemically identified subpopulations of neurons in the prefrontal cortex of the macaque monkey. J Neurosci 13:2982-2992.

von Bonin G, Mehler WR (1971) On columnar arrangement of nerve cells in cerebral cortex. Brain Res 27:1-10.

Wada K, Dechesne CJ, Shimasaki S, King RG, Kusano K, Buonanno A, Hampson DR, Banner C, Wenthold R J, Nakatani Y (1989) Sequence and expression of a frog brain complementary DNA encoding a kainate-binding protein. Nature 342:684-689.

Walker AE (1940) A cytoarchitectural study of the prefrontal area of the macaque. J Comp Neurol 73:59-86.

Watkins JC, Krogsgaard-Larsen P, Honore T (1991) Structure-activity relationships in the development of excitatory amino acid receptor agonists and competitive antagonists. Trends Pharmacol Sci 11:4 12.

Wenthold RJ, Yokotani N, Doi K, Wada K (1992) Immunochemical characterization of the non-NMDA glutamate receptor using subunitspecific antibodies. J Biol Chem 267:501-507.

Werner P, Voigt M, Keinanen K, Wisden W, Seeburg PH (1991) Cloning of a putative high-affinity kainate receptor expressed predominantly in hippocampal C.A3 cells. Nature 351:742-744

White EL (1989) Cortical circuits. Synaptic organization of the cerebral cortex: structure, function and theory, pp 46-82. Boston: Birkhauser. 